\title{
Actein induces autophagy and apoptosis in human bladder cancer by potentiating ROS/JNK and inhibiting AKT pathways
}

\author{
Lu Ji ${ }^{1}$, Bing Zhong ${ }^{1}$, Xi Jiang ${ }^{1}$, Fei Mao ${ }^{1}$, Gang Liu ${ }^{2}$, Bin Song ${ }^{3}$, Cheng-Yuan Wang ${ }^{3}$, \\ Yong Jiao ${ }^{3}$, Jiang-Ping Wang ${ }^{3}$, Zhi-Bin $\mathrm{Xu}^{3}$, Xing $\mathrm{Li}^{3}$ and Bo Zhan ${ }^{3}$ \\ ${ }^{1}$ Department of Urology, Huai'an First People's Hospital, Nanjing Medical University, Huai'an 223300, China \\ ${ }^{2}$ Department of Orthopaedics, Huai'an First People's Hospital, Nanjing Medical University, Huai'an 223300, China \\ ${ }^{3}$ Branch of Raw Material and Natural Products, Far East Biological Products Co. LTD., Nanjing 210009, China \\ Correspondence to: Gang Liu, email: 1345297715@qq.com, Igpite2008@163.com
}

Keywords: human bladder cancer, Actein (ACT), autophagy and apoptosis, ROS and JNK, AKT

Received: July 03, $2017 \quad$ Accepted: September 20, $2017 \quad$ Published: November 01, 2017

Copyright: Ji et al. This is an open-access article distributed under the terms of the Creative Commons Attribution License 3.0 (CC BY 3.0), which permits unrestricted use, distribution, and reproduction in any medium, provided the original author and source are credited.

\section{ABSTRACT}

Human bladder cancer is a common genitourinary malignant cancer worldwide. However, new therapeutic strategies are required to overcome its stagnated survival rate. Triterpene glycoside Actein (ACT), extracted from the herb black cohosh, suppresses the growth of human breast cancer cells. Our study attempted to explore the role of ACT in human bladder cancer cell growth and to reveal the underlying molecular mechanisms. We found that ACT significantly impeded the bladder cancer cell proliferation via induction of G2/M cycle arrest. Additionally, ACT administration triggered autophagy and apoptosis in bladder cancer cells, proved by the autophagosome formation, LC3B-II accumulation, improved cleavage of Caspases/poly (ADP-ribose) polymerase (PARP). Furthermore, reduction of reactive oxygen species (ROS) and p-c-Jun N-terminal kinase (JNK) could markedly reverse ACT-induced autophagy and apoptosis. In contrast, AKT and mammalian target of rapamycin (mTOR) were greatly de-phosphorylated by ACT, while suppressing AKT and mTOR activity could enhance the effects of ACT on apoptosis and autophagy induction. In vivo, ACT reduced the tumor growth with little toxicity. Taken together, our findings indicated that ACT suppressed cell proliferation, induced autophagy and apoptosis through promoting ROS/JNK activation, and blunting AKT pathway in human bladder cancer, which indicated that ACT might be an effective candidate against human bladder cancer in future.

\section{INTRODUCTION}

Human bladder cancer is one of the most common genitourinary malignant cancers, leading to health issue worldwide $[1,2]$. Presently, the existed therapeutic strategies, including radical cystectomy and chemotherapy, are far from to be satisfied considering the metastases and recurrence of human bladder cancer [3-5]. Thus, although advances have been made in radiotherapy, perioperative chemotherapy, and surgical technology, the 10-year survival rate remains grave after radical cystectomy $[3,6]$. Hence, it is still urgently to find and develop new and effective strategies against bladder cancer.
The purified triterpene glycoside actein ( $\beta$-Dxylopyranoside, ACT), isolated from black cohosh, was suggested to be effective against human breast cancer cells $[7,8]$. Black cohosh was applied by the Native Americans for its anti-inflammatory and attenuated menopausal symptoms [9]. And it has been suggested that black cohosh may have chemo-preventive and anti-cancer potential [10]. The rhizomes and roots of the plant contain two major classes of secondary metabolites, triterpene glycosides and phenylpropanoids $[11,12]$. The triterpene glycosides actein constitutes about $6.4 \%$ of an n-butanolic fraction of black cohosh enriched for triterpene glycosides (27\%) [13]. Purified triterpene glycosides have been shown to inhibit the growth of various types of cancer cells in vitro, including 
human oral squamous carcinoma cells, breast cancer cells and liver cancer cells [14-16]. Triterpene glycosides from black cohosh have been shown to induce cell-cycle arrest at G1 [15]. Additionally, ACT could synergize with various kinds of chemotherapy agents at low doses to suppress the growth of cancer cells [17]. The growth-inhibitory effects of ACT may be associated with the altered expression of genes involved in the stress response pathways, the unfolded protein response and cell cycle control genes [18]. The bioactivity results for ACT should be helpful to elucidate its medical value to prevent human bladder cancer. Actually, it was the first time that ACT was investigated to indicate if it could inhibit the progression of bladder cancer and to reveal the underlying molecular mechanisms.

The cell cycle is associated with strict events, which modulate the cell division and proliferation through alterations of cyclin-dependent kinases (CDKs) and cyclins, leading to the transition in the process of cell cycle $[19,20]$. During this event, dysfunctional expression of genes arrested or delayed checkpoints prior to cell division [21-23]. Thus, abnormal expression of CDKs or cyclins disorganized the process of cell division, contributing to the occurrence and progression of various tumors [24, 25]. And a variety of proteins, including p53, p21, and Cdc25C, play essential roles in controlling the expression of CDKs and Cyclins to regulate cell proliferation [26-28].

Autophagy is a lysosomal-dependent degradation process induced under various conditions or stresses [29]. Autophagy is reported as an alternative molecular mechanism by which the cell death is induced [30]. There is evidence that autophagy is needed for the death of cancer cells with defects in apoptosis [31]. In addition, new insights of the molecular mechanisms of autophagy are major reasons for the exploration of new potential drug targets [32, 33]. Induction of apoptosis presents an essential mechanism for drug-exploration against various cancers [34]. In general, there are two main apoptotic pathways: the intrinsic and the extrinsic [35]. The two pathways converge on the activation of Caspases, which contain a family of cysteine proteases and play an essential role in the completion of apoptosis [36, 37]. Accordingly, previous studies have pointed out that autophagy and apoptosis are tightly connected and may be modulated by ROS and JNK [38]. There is intriguing evidence that excessive ROS generation overcomes the cellular anti-oxidant defenses, inducing apoptosis [39]. Further, most cancer cells are more sensitive to rapid generation of ROS levels than normal cells [38, 40]. The phosphorylation of JNK is linked to ROS elevation $[38,41]$. The JNK phosphorylation activated via ROSdependent pathway triggers the over-expression of tumor suppressors, resulting in cell apoptosis [42]. Recently, AKT pathway is reported to suppress the formation of autophagy, and a large number of drugs are reported to treat the development of cancers via suppressing AKT phosphorylation.
In our study, the effects of ACT on human bladder cancer in vitro and in vivo were investigated. And the possible molecular mechanism by which the bladder cancer was suppressed was also explored, which were dependent on ROS/JNK- and AKT-regulated apoptosis and autophagy induction.

\section{RESULTS}

\section{Actein suppresses cell proliferation in human bladder carcinoma cell lines}

In order to explore the anti-proliferative effects of ACT on human bladder cancer, human bladder cancer cell lines, BIU-87, T24, T739 and 5637 were cultured with various concentrations of ACT for 24 and $48 \mathrm{~h}$, followed by the assessment of cell viability using MTT analysis. As shown in Figure 1A, we found that the cell viability of human bladder cancer cells was dramatically downregulated by ACT treatment in a dose- and time-dependent manner. Additionally, human normal bladder cell line of SV-HUC-1 and human normal liver cell line of L-02 were involved to further investigate the effects of ACT on noncancer cell lines. From Figure 1B, SV-HUC-1 cells were not sensitive to ACT treatment, only at the treatment of highest dose of $40 \mathrm{uM}$ for $48 \mathrm{~h}$, significant difference was observed. Furthermore, administration of ACT for $72 \mathrm{~h}$, both at 20 and $40 \mathrm{uM}$, exhibited relatively apparent difference compared to the control group without any treatment. Next, the cologenic assays were performed to calculate the role of ACT in regulating colony formation. The results indicated that ACT treatment considerably reduced the number of colonies of human bladder cancer cells in a dose-dependent manner (Figure 1C). The results above indicated that ACT suppressed the proliferation of human bladder cancer cells in a concentration- and timedependent manner, exhibiting unconspicuous cytotoxicity to non-cancer cell lines, and that ACT might be used as a promising candidate against human bladder cancer.

\section{Actein induces G2/M cell cycle arrest in human bladder cancer cells}

In this regard, to verify if the growth suppression caused by ACT is associated with cell cycle arrest, the role of ACT in the cell cycle distribution was measured. As shown in Figure $2 \mathrm{~A}-2 \mathrm{C}$, the proportion of bladder cancer cells at G1/S was significantly decreased after ACT treatment, while the percentage of cancer cells at G2/M phase was markedly increased owing to ACT treatment (0, 5,10 , and $20 \mathrm{uM}$ ) for $24 \mathrm{~h}$. Subsequently, the cell cycleassociated molecules were evaluated using western blot analysis. The results exhibited that ACT enhanced p53, p21, p-Cdk1, Cyclin B and p-Cdc25C, while reduced 14$3-3 \sigma$ in a dose-dependent manner, which were related to the regulation of $\mathrm{G} 2 / \mathrm{M}$ cell cycle arrest (Figure 2D). In 
contrast, p-Cdk2 and Cyclin A were dose-dependently down-regulated by $\mathrm{ACT}$, associated with the reduction of $\mathrm{G} 1 / \mathrm{S}$ phase (Figure 2E). In conclusion, the findings above suggested that ACT induced G2/M cell cycle arrest through modulating the important signals of $\mathrm{G} 2 / \mathrm{M}$ cell cycle transition-phase.

\section{Actein triggers autophagy in human bladder cancer cells}

Autophagy is characterized by the enhanced acidic vesicular organelles, which has a close relationship with the formation of autophagosomes, and then the autophagosome fuses with the lysosome, forming autophagolysosome [23, 25, 28]. Enhancement of autophagic cell death from cancer cells is one of the best strategies in chemotherapy $[27,28]$. Thus, we explored if or not ACT could trigger autophagy in human bladder cancer cells. At the beginning, the LysoTracker Red staining was used to mark the cellular acidic components, including autophagosomes and lysosomes. As shown in Figure 3A, the bladder cancer cells treated with ACT exerted more acidic vesicular organelles around the nucleus of cytoplasm in a dose-dependent manner. Following, the GFP-LC3 puncta transfection was applied to evaluate the condition of fluorescent puncta of autophagosomes. Figure 3B indicated that intensive GFPLC3 puncta formation was observed in ACT-treated groups of bladder cancer cell lines. Next, the electric microscopy analysis revealed that ACT treatment significantly damaged bladder cancer cells that exhibited the shrunken state with an intact membrane, aggregated chromatin and pseudopodia-like protrusions, while the normal bladder cancer cells showed well-distributed chromatin and a clear nuclear membrane (Figure 3C). When cells undergo autophagic cell death, Microtubule-associated protein 1A/1B-light chain 3 (LC3)-II, an autophagosomal marker, increases from the conversion of LC3-I [43]. Western blot analysis indicated that LC3BI and LC3BII, and Beclin 1, involved in autophagy formation, were found to be highly
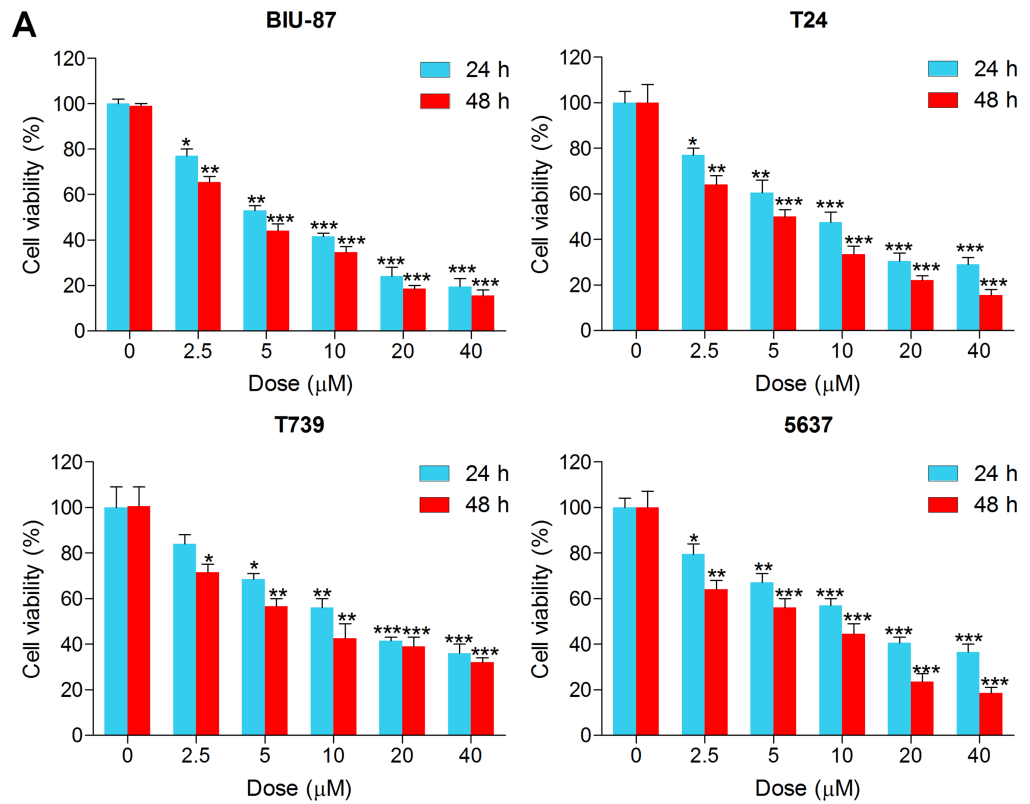

C

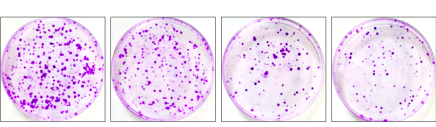

BIU-87

B

SV-HUC-1
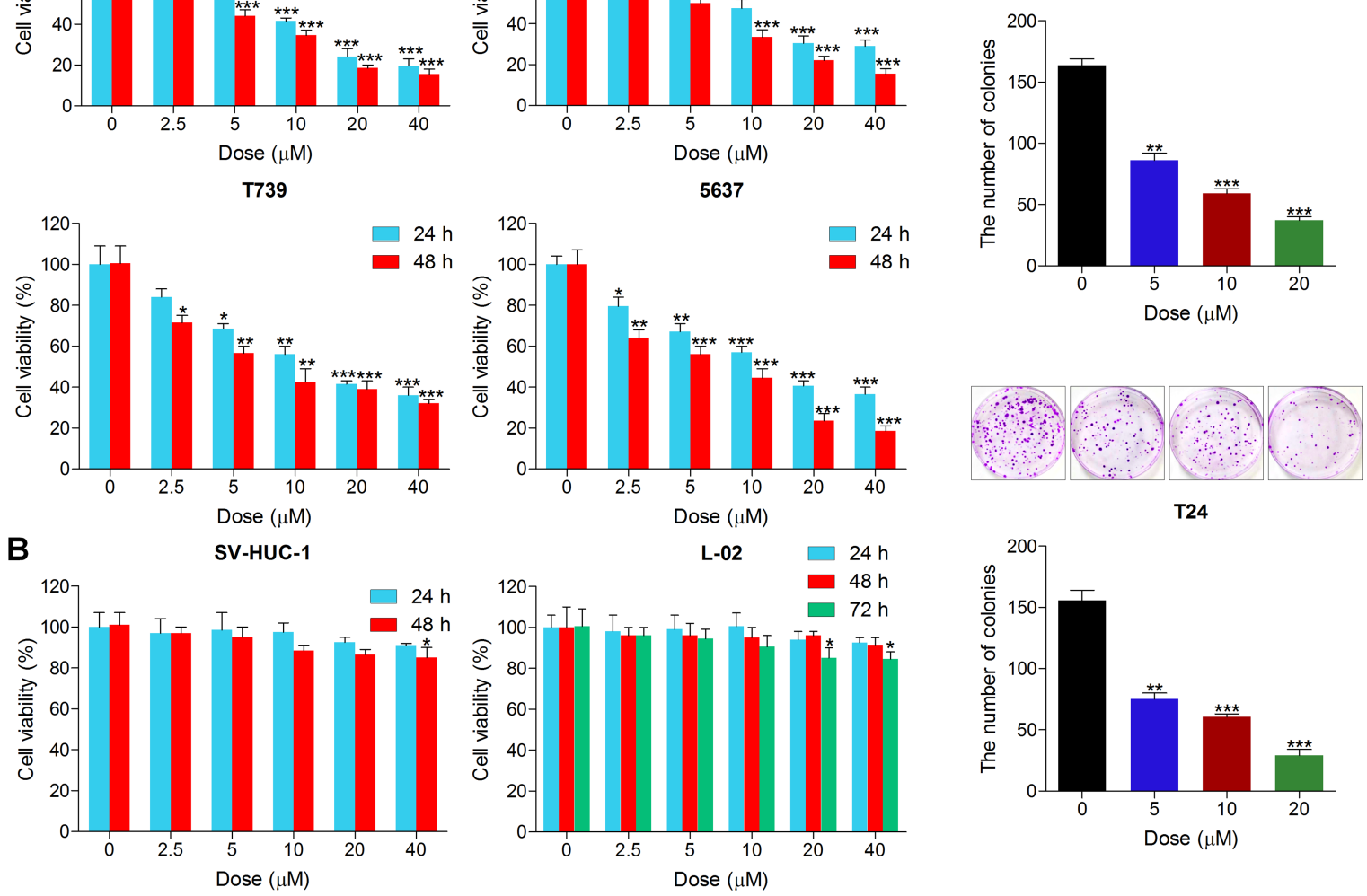

Figure 1: Actein suppresses cell proliferation in human bladder carcinoma cell lines. (A) Human bladder cancer cell lines of BIU-87, T24, T739 and 5637 were treated with different concentrations $(0,2.5,5,10,20$ and $40 \mathrm{uM})$ of ACT for $24 \mathrm{~h}$ or $48 \mathrm{~h}$, followed by MTT analysis to calculate the cell viability. (B) Human normal bladder cell line of SV-HUC-1 and human normal liver cell line of L-02 were cultured with ACT at the indicated doses for 24,48 or $72 \mathrm{~h}$, and then the cell viability was measured using MTT analysis. (C) Human bladder cancer lines of BIU-87 and T24 were treated with different doses of ACT for $24 \mathrm{~h}$, followed by clonogenic assays. Data are represented as mean \pm S.E.M. ${ }^{*} p<0.05,{ }^{* *} p<0.01,{ }^{* * *} p<0.001$ versus the untreated group. 
induced by ACT culture in a dose-dependent manner, while p62 was greatly reduced (Figure 3D). According to previous studies, autophagy could protect the cell survival and induce cell death through various pathways [44]. In order to calculate if ACT-induced autophagy is a pro-death way or a pro-survival way, 3-MA, as essential autophagy inhibitor, was applied to pre-incubate the bladder cancer cells, followed by ACT treatment. Figure 3E suggested that administration with 3-MA enhanced the suppressive effect of ACT on bladder cancer cell viability. Similarly, the colony formation of human bladder cancer cells was dramatically inhibited by co-treatment with 3-MA (Figure 3F). Taken together, the data above indicated that
ACT triggered autophagy in bladder cancer cells, which might be in a pro-survival way.

\section{Actein induces apoptosis in human bladder carcinoma cells}

Apoptosis is a mode of cell death in which single cells are eliminated in the midst of living tissue, which is a key molecular mechanism by which anti-cancer drugs were investigated [36, 37, 40]. Hence, if apoptosis involved in the suppression of bladder cancer cells by ACT was further explored. As shown in Figure 4A and 4B, Hoechst 33258 staining and TUNEL analysis
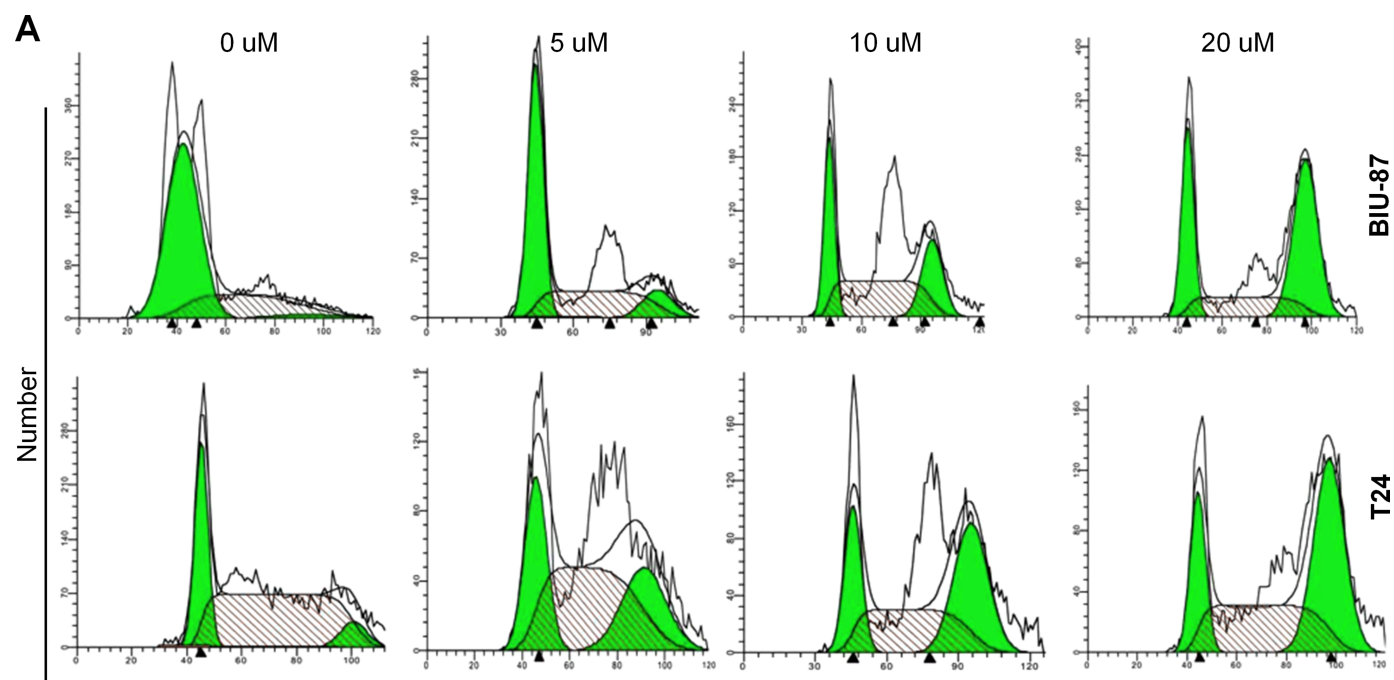

B

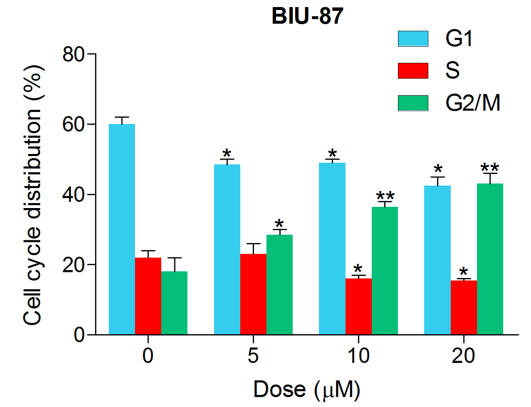

D

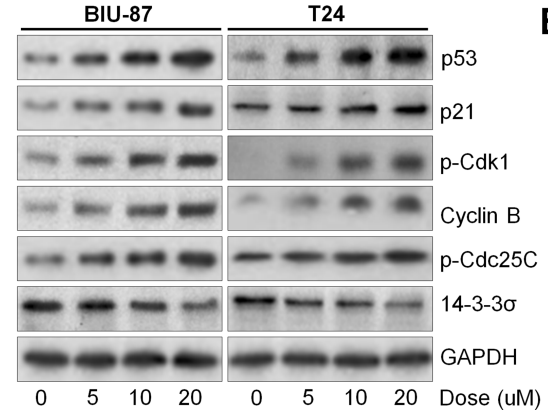

C

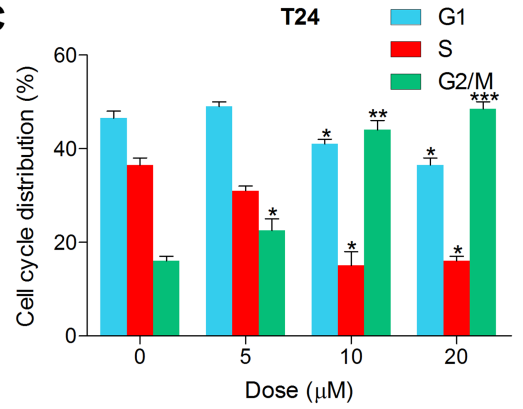

E

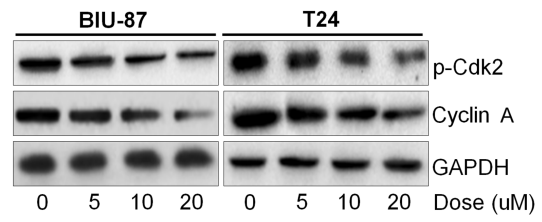

Figure 2: Actein induces G2/M cell cycle arrest in human bladder cancer cells. (A) BIU-87 and T24 cells were cultured with $\mathrm{ACT}$ at the described concentrations for $24 \mathrm{~h}$, and then flow cytometry analysis was used to calculate the cell cycle distributions. (B, C) The quantification of cell cycle arrest in ACT-treated BIU-87 and T24 cells were shown. (D) Signals associated with G2/M transition were investigated using western blot analysis. (E) Proteins involved in G1/S transition were measured through immunoblotting analysis. Data are represented as mean \pm S.E.M. ${ }^{*} p<0.05,{ }^{* *} p<0.01,{ }^{* * *} p<0.001$ versus the untreated group. 
indicated that ACT significantly induced apoptosis along with nuclei fragmentation, chromatin condensation and cell shrinkage. And TUNEL-positive intensity through confocal microscope was highly enhanced by ACT administration. Moreover, flow cytometry analysis indicated that both early and late apoptosis cells were dose-dependently elevated by ACT treatment (Figure $4 \mathrm{C}$ and 4D). Furthermore, JC-1 and JC-10 levels were

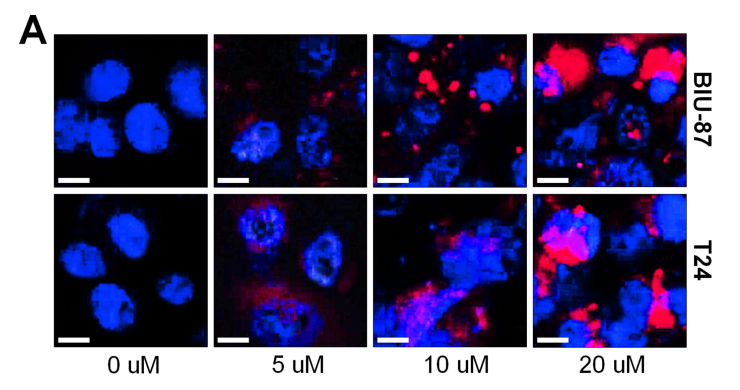

D
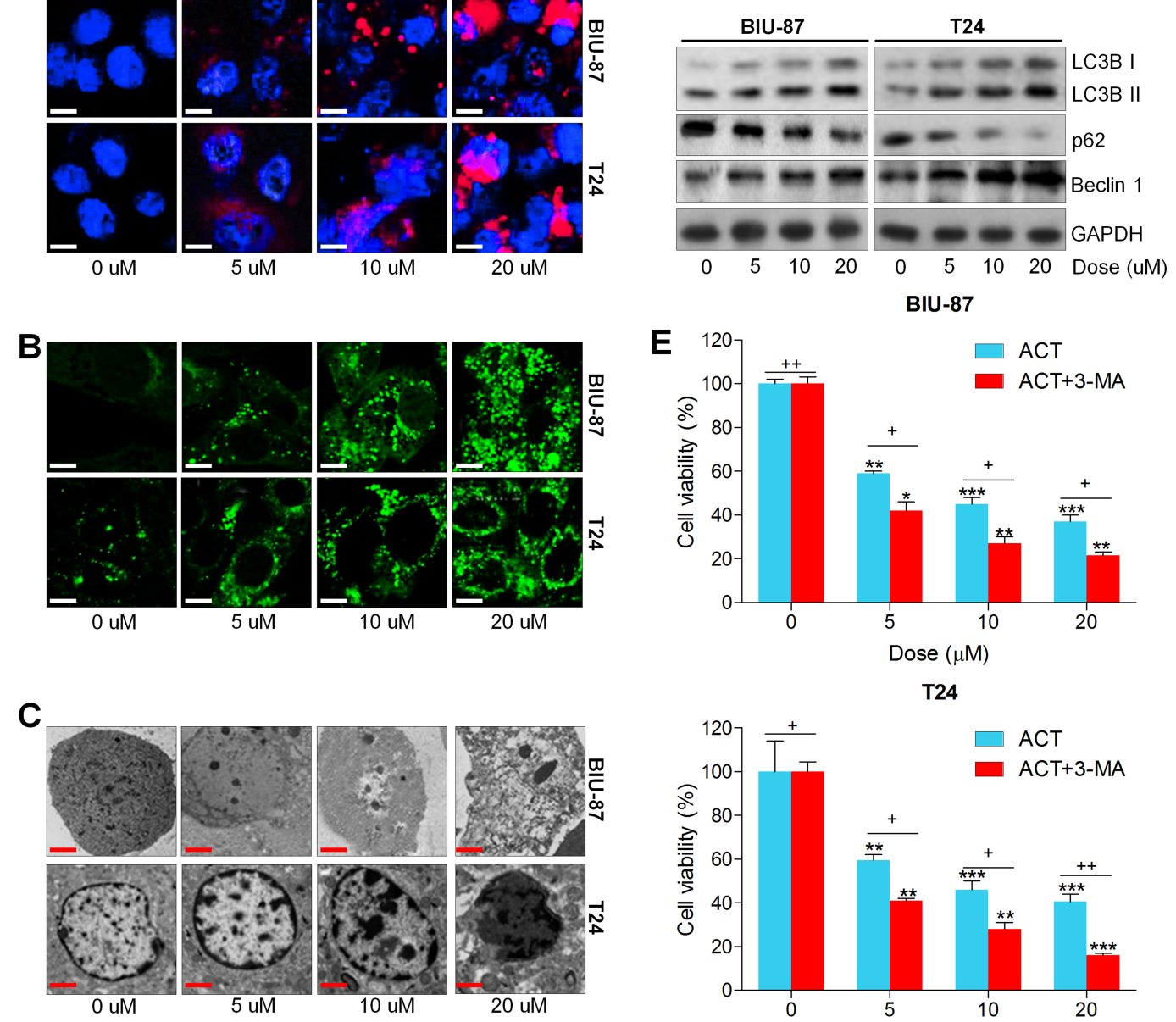

T24
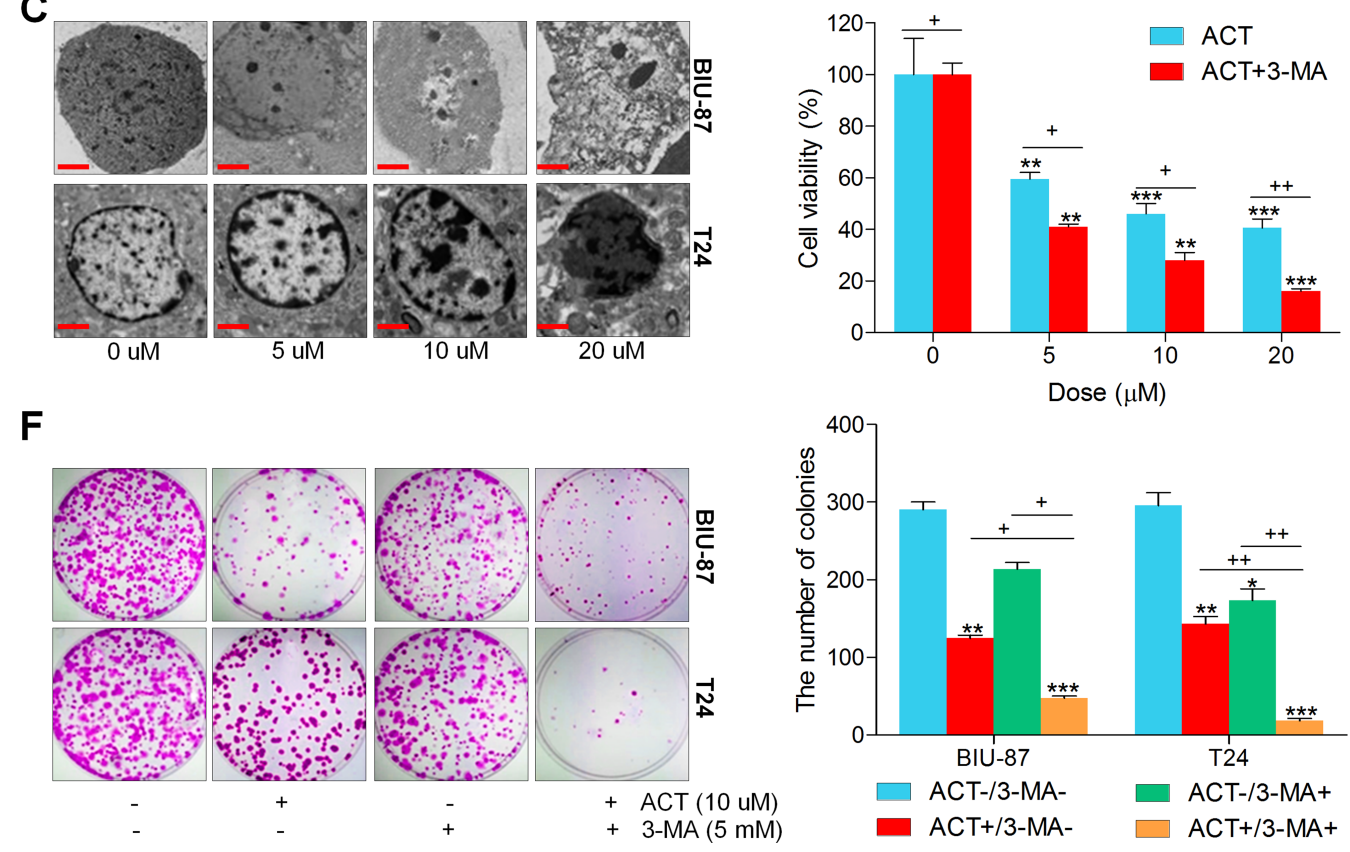

Figure 3: Actein triggers autophagy in human bladder cancer cells. (A) Human bladder cancer cell lines of BIU-87 and T24 were exposed to ACT for $24 \mathrm{~h}$. Then, all cells were harvested for LysoTracker Red DND-99 (50 nM) analysis to evaluate the cellular acidic compartments, revealing the autolysosomes and lysosomes situations. (B) BIU-87 and T24 cells were pre-transfected with GFP-LC3 plasmid for $24 \mathrm{~h}$, followed by ACT administration for another $24 \mathrm{~h}$ at the described concentrations. And confocal microscope was used to observe the images of GFP-LC3 fusion proteins. The fluorescent intensity refers to the formation of autophagosomes. (C) BIU-87 and T24 cells were incubated with ACT for $24 \mathrm{~h}$, and then all cells were collected for transmission electron microscopy (TEM) analysis. (D) Autophagy-related proteins, including LC3BI/II, p62 and Beclin 1, were assessed using western blot analysis. (E, F) BIU-87 and T24 cells were pre-treated with 3-MA $(5 \mathrm{mM})$ for $2 \mathrm{~h}$, followed by various ACT exposure for another $24 \mathrm{~h}$. Then, all cells were collected for MTT and colony formation assays through cologenic analysis. Data are represented as mean \pm S.E.M. ${ }^{*} p<0.05,{ }^{* *} p<0.01,{ }^{* * *} p<0.001$ versus the untreated group; ${ }^{+} p<0.05$ and ${ }^{++} p<0.01$. 
assessed to evaluate the mitochondrial membrane potential. Figure 4E and 4F revealed that the fluorescent intensities for both J-aggregates and monomeric forms of JC-1 and JC-10 were dramatically enhanced by ACT in a dose-dependent manner in both BIU-87 and T24 cells. Also, the western blot results indicated that cleaved Caspase-3, PARP, Casapse- 8 and Caspase-9 were all considerably enhanced by ACT (Figure 4G). Also, antiapoptotic and pro-apoptotic molecules were measured by immunoblotting analysis. Figure $4 \mathrm{H}$ indicated that $\mathrm{B}$ cell CLL/lymphoma 2 (Bcl-2) and Myeloid Cell Leukemia-1 (Mcl-1), as important anti-apoptotic signals, were reduced by ACT administration, while Bax, Bad and Bim were augmented dose-dependently, indicating pro-apoptosis. The results above revealed that cell apoptosis was induced by ACT through both intrinsic and extrinsic pathways.

\section{Actein-induced apoptosis is enhanced by suppressing autophagy}

Previous studies indicated that autophagy could modulate apoptosis to infect the cell survival or death [45]. Therefore, here we further used 3-methyladenine (3-MA) combined with or without ACT to investigate the molecular mechanism. As shown in Figure 5A, we found that pre-treatment with 3-MA together with ACT significantly enhanced cleaved Caspase-3, PARP, Casapse- 8 and Caspase-9. Reduced levels of Bcl-2 and Mcl-1 were observed in 3-MA/ACT groups. In contrast, $\mathrm{Bax}$, Bad and Bim were highly induced by 3-MA and ACT co-culture (Figure 5B). Also, flow cytometry analysis directly demonstrated that both early and late apoptosis in bladder cancer cells were dramatically induced due to ACT and 3-MA co-treatment (Figure 5C and 5D). Finally, JC-1 and JC-10, indicating mitochondrial potential, were similarly found to be triggered owing to 3-MA/ ACT treatment (Figure 5E and 5F). Thus, the results above indicated that treatment with 3-MA promoted ACT apoptotic effects. And the autophagy induced by ACT might be pro-survival.

\section{Actein potentiates ROS generation and JNK phosphorylation, and suppresses AKT pathway}

ROS generation is a crucial modulator in a variety of signaling pathways, which are associated with autophagy and apoptosis [38, 39]. Augment of DCF fluorescence in bladder cancer cells after ACT treatment was observed compared to the control group in the absence of ACT (Figure 6A). MitoSOX Red, an indicator of oxidationsensitive red fluorescence, was used to further explore the role of ACT in regulating ROS generation. As shown in Figure 6B, we found that BIU-87 and T24 cells after ACT treatment exhibited dose-increased MitoSOX Red fluorescence, further indicating the elevation of ROS. Following, ROS scavenger of N-acetyl cysteine (NAC) was further treated to bladder cancer cells. Figure 6C indicated that ACT-induced ROS production was significantly reduced by NAC. Consistently, ACT-caused increased MitoSOX Red fluorescence was also scavenged by NAC (Figure 6D).

In order to further reveal the underlying molecular mechanism of the anti-cancer effects of ACT, the AKT and JNK signaling pathways were investigated using western blot analysis. AKT signaling pathway is considered to negatively modulate autophagy and apoptosis [46]. Figure $6 \mathrm{E}$ indicated that ACT dose-dependently reduced the AKT/mTOR and JAK2/STAT3 activity, while p38 and JNK were highly phosphorylated.

\section{The effects of ROS and p-JNK in cell cycle arrest, apoptosis and autophagy triggered by actein in human bladder cancer cells}

ROS production is reported to be an essential regulator or inducer for apoptosis, autophagy and JNK activation to influence cell proliferation [47, 48]. As shown in Supplementary Figure $1 \mathrm{~A}$ and 1B, NAC and JNK inhibitor of SP600125 were pre-treated to BIU-87 and T2 4 cells for $2 \mathrm{~h}$, followed by ACT culture for another $24 \mathrm{~h}$. And MTT analysis indicated that ACT-reduced cell viability was reversed for NAC pre-treatment, which was comparable to the ACT-treated groups. Additionally, SP600125 also reversed the cancer cell death caused by ACT in bladder cancer cells (Supplementary Figure 1B). Furthermore, flow cytometry assays suggested that both NAC and SP600125 significantly impeded ACT-induced G2/M cell cycle arrest, while induced G1/S phase arrest (Supplementary Figure 1C). And NAC showed more suppressive role in the induction of $\mathrm{G} 2 / \mathrm{M}$ phase arrest for ACT treatment. Western blot analysis further revealed that both in BIU-87 and T24 cells, pre-incubation with NAC and SP600125 reversed the phosphorylated p38 and JNK levels induced by ACT, which was along with the reduced cleavage of Caspase-3, PARP, Casapse-8 and Caspase-9, as well as LC3BI/II, Beclin 1 and p53 (Supplementary Figure 1D and 1E). In conclusion, the data above indicated that ACT could induce ROS generation and activate JNK expression, whereas suppress AKT pathway, which might be linked to cell proliferation, apoptosis and autophagy triggered by ACT in human bladder cancer cells.

\section{AKT pathway is involved in cell cycle arrest, apoptosis and autophagy triggered by actein in human bladder cancer cells}

On the contrary to the role of NAC as well as SP600125, AKT inhibitor, MK2206, significantly elevated the role of ACT in inducing bladder cancer cell death (Supplementary Figure 2A). Also, pretreatment with rapamycin (RAPA), mTOR suppressor, ACT exhibited enhanced effects on the induction of cell 
death (Supplementary Figure 2B). Following, the flow cytometry analysis suggested that both MK2206 and RAPA dramatically up-regulated G2/M arrest, and downregulated G1/S phase arrest in human bladder cancer cells ACT with ACT induction (Supplementary Figure 2C). In Supplementary Figure 2D and 2E, MK2206 and RAPA greatly enhanced apoptosis- and autophagy-associated proteins in bladder cancer cells either with or without ACT treatment. At the same time, MK2206 and RAPA observably promoted p38 and JNK phosphorylation induced by ACT. The findings above indicated that apoptosis and autophagy triggered by ACT in human bladder cancer cells could be potentiated by suppressing AKT signaling pathway.

\section{Actein inhibits the growth of human bladder xenograft mice in vivo}

In order to verify the anti-cancer role of ACT in bladder cancer cells in vivo, an intracranial nude mouse model was established using BIU-87 cells. BIU-87 cells were injected into the flanks of athymic nude mice to establish the xenograft tumors. When the tumor size reached to about $50 \mathrm{~mm}^{3}$, all mice were separated into
A

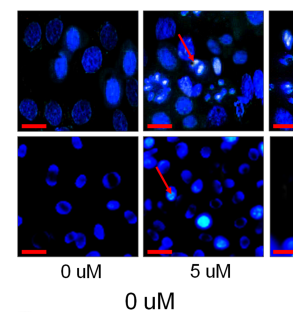

C

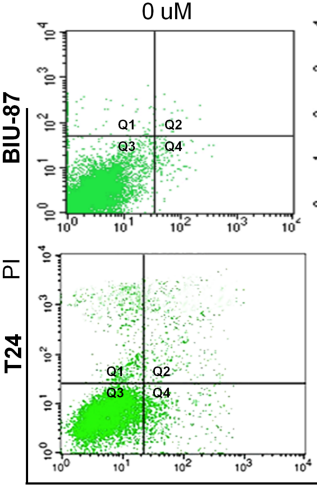

B
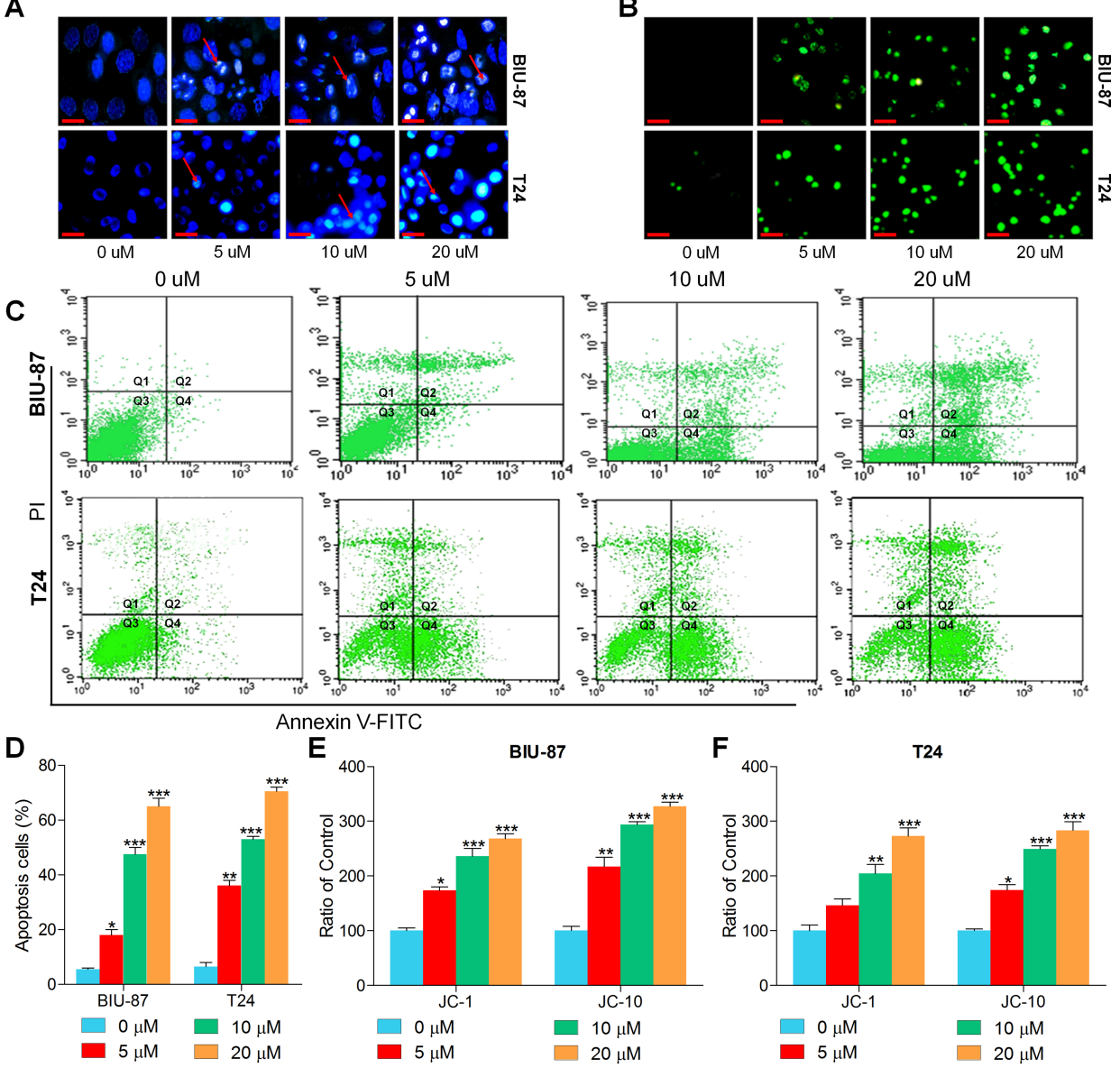

Annexin V-FITC
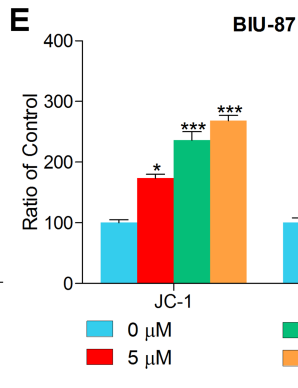

G

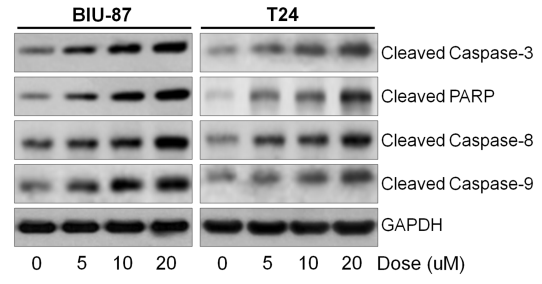

$\mathbf{F}$

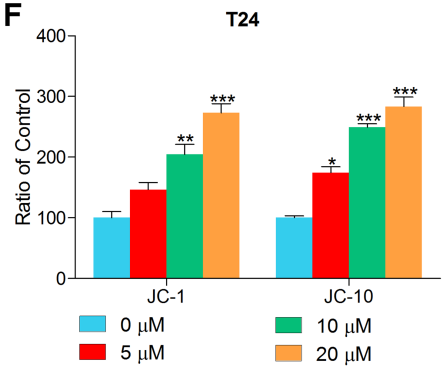

H BIU-87

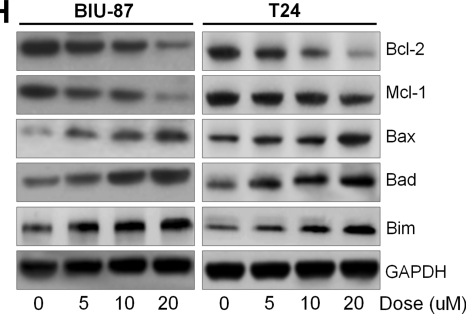

Figure 4: Actein induces apoptosis in human bladder carcinoma cells. (A) BIU-87 and T24 cells were incubated with ACT for $24 \mathrm{~h}$, followed by Hoechst 33258 analysis. (B) TUNEL assays were applied to explore the apoptosis in cells. (C) Bladder cancer cells were cultured with ACT for $24 \mathrm{~h}$, and then analyzed through flow cytometry. (D) The apoptosis proportion of bladder cancer cells was shown following flow cytometry. (E, F) BIU-87 and T24 cells were treated with ACT for $24 \mathrm{~h}$, and then the mitochondrial membrane potential was verified through measuring JC-1 and JC-10 levels. And the ratio of control was displayed. (G) Western blot analysis of cleaved Caspase-3, PARP, Caspase-8 and Caspase-9. (H) The western blot analysis of Bcl-2, Mcl-1, Bax, Bad and Bim. Data are represented as mean \pm S.E.M. ${ }^{*} p<0.05,{ }^{* *} p<0.01,{ }^{* * *} p<0.001$ versus the untreated group. 
four groups $(0,10,20$, and $30 \mathrm{mg} / \mathrm{kg})$. As shown in Figure $7 \mathrm{~A}$, the growth of tumor was markedly reduced by ACT administration in a dose-dependent manner, evidenced by tumor size and tumor weight measurement. Meanwhile, there was no significant alteration in body weight and liver weight among different groups of mice (Figure 7B and $7 \mathrm{C}$ ). In addition, serum ALT and AST, indicating hepatic toxicity, in mice treated with different doses of ACT were found to be similar in each group (Figure 7D). Figure 7E indicated that there was no obvious difference of BUN and CREB in ACT-treated groups. Finally, H\&E staining suggested that ACT administration exhibited no histology changes in each group of mice (Figure 7F). The results here indicated that ACT suppressed human bladder cancer progression in vivo with low toxicity to animal bodies.

H\&E staining of tumor tissue sections indicated that ACT reduced the number of tumor cells. And the immunohistochemical analysis suggested lower levels of KI-67 positive cells while higher levels of TUNELpositive cells in ACT-treated tumors, which were comparable to the control ones (Figure $8 \mathrm{~A}$ and $8 \mathrm{~B}$ ). In addition, western blot analysis demonstrated that ACT improved the expression levels of cleaved Caspase-3, PARP, Casapse-8 and Caspase-9, as well as LC3BI/II and Beclin 1, which are associated with apoptosis and
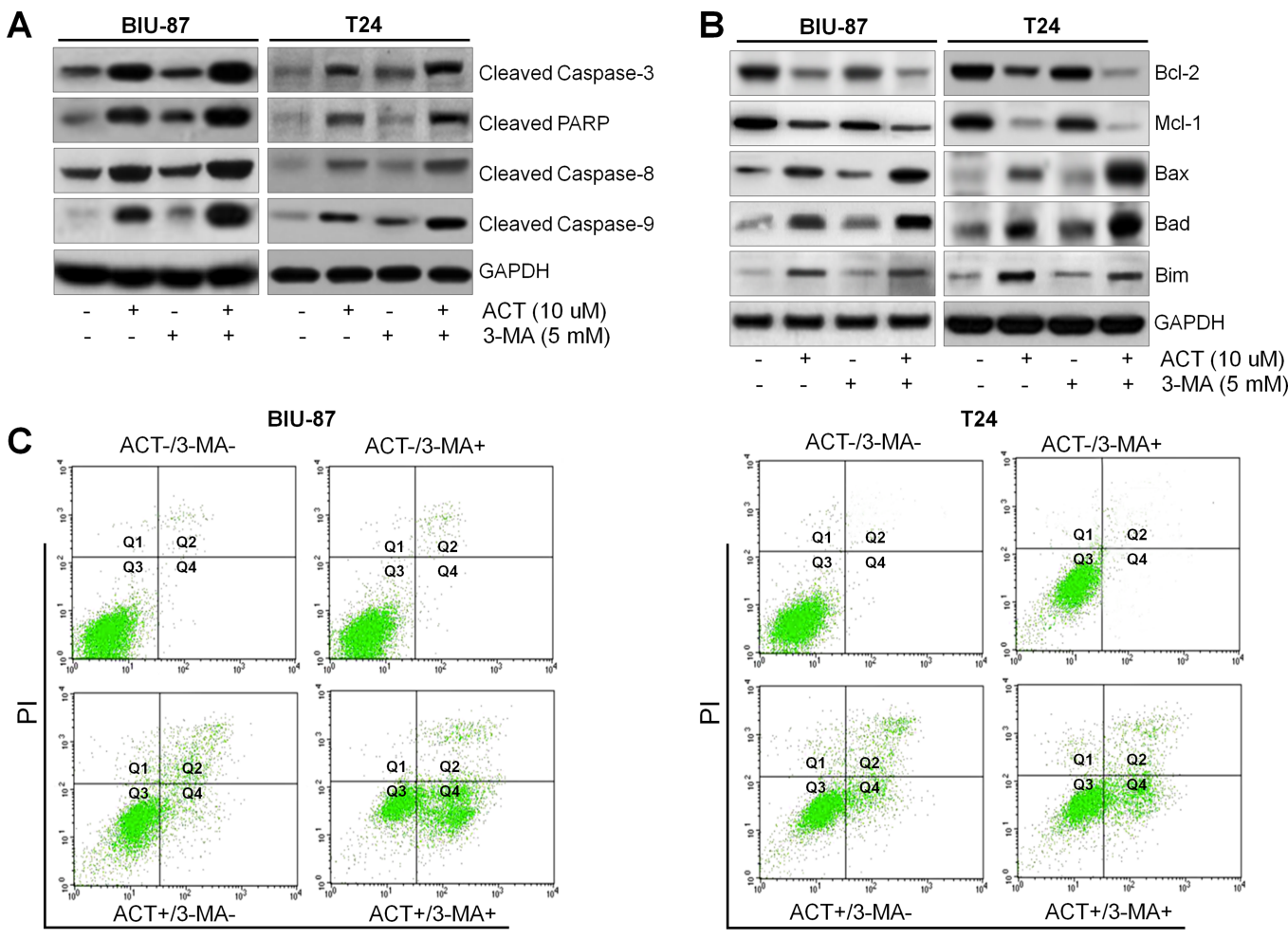

T24

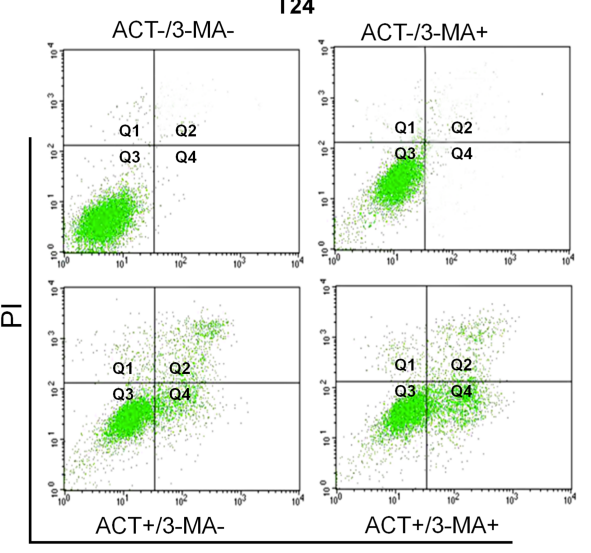

Annexin V-FITC
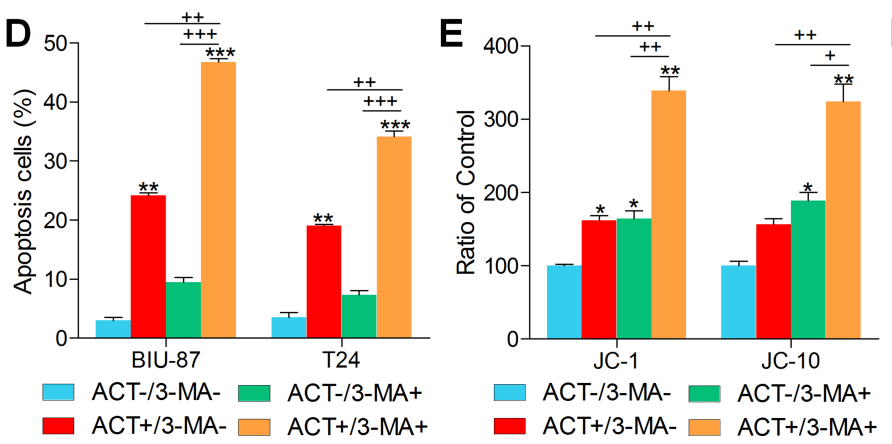

Annexin V-FITC

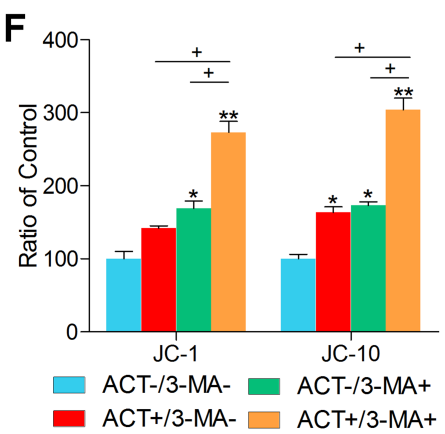

Figure 5: Actein-induced apoptosis is enhanced by suppressing autophagy. BIU-87 and T24 cells were pre-incubated with 3-MA for $2 \mathrm{~h}$, followed by ACT treatment for another $24 \mathrm{~h}$. (A, B) Then, western blot analysis was used to evaluate the apoptosis-related signals. (C) BIU-87 and T24 cells were pre-treated with 3-MA for $2 \mathrm{~h}$, followed by ACT exposure for another $24 \mathrm{~h}$. Then, all cells were harvested for flow cytometry analysis to assess the apoptosis. (D) The quantification of apoptosis proportion was exhibited following the flow cytometry assays. (E, F) BIU-87 and T24 cells were treated as described, and then the mitochondrial membrane potential was measured through assessing JC-1 and JC-10 levels. The ratio of control was exhibited. Data are represented as mean $\pm \mathrm{S} . \mathrm{E} . \mathrm{M}$. ${ }^{*} p<0.05,{ }^{* *} p$ $<0.01,{ }^{* * *} p<0.001$ versus the untreated group $;{ }^{+} p<0.05,{ }^{++} p<0.01$ and ${ }^{+++} p<0.001$. 
autophagy. p-AKT and p-mTOR were dose-dependently reduced by ACT, whereas JNK phosphorylation was elevated in tumor tissue segments (Figure 8B). In conclusion, the data above indicated that ACT suppressed human bladder cancer growth in vivo through inducing apoptosis and autophagy.

\section{DISCUSSION}

Bladder cancer is a highly prevalent tumor and is related to substantial morbidity, mortality and cost $[1,2,49]$. The environmental or occupational exposures to carcinogens, particularly tobacco, are the major risk factors for promoting the bladder cancer [50, 51]. Currently, despite huge advances have been made, the therapeutic strategies for human bladder cancer are still limited. Thus, it is necessary to find new and novel treatments to prevent human bladder cancer progression. Actein is a bioactive triterpene glycoside, which is isolated from Cimicifuga species, and has been revealed for its suppressive effects on the growth and proliferation of breast cancer cells and osteoblastic cells $[9,10,19,20]$.
Considering its effective role in preventing cancer cells, as well as its long historic application in Asia, actein was used in our study to further reveal its anti-cancer ability. As we know, it was the first time that ACT was investigated in human bladder cancer. Here, we further found that ACT could inhibit cell proliferation, induce G2/M phase and reduce $\mathrm{G} 1 / \mathrm{S}$ phase, and trigger autophagy and apoptosis in human bladder cancer cells. Of note, ACT at the same time potentiated ROS generation and JNK activation, while impeded AKT and mTOR activity both in vitro and in vivo, which was tightly involved in the induction of apoptosis and autophagy. In vivo experiments further confirmed that ACT greatly suppressed the tumor growth of nude mice bearing BIU-87 cells.

Dysfunction of cell cycle arrest is an essential marker for cancer progression [19-21, 52]. Many anticancer agents reduce malignant growth by arresting the cell cycle at the G1/S or G2/M phases [53]. According to previous studies, cell cycle arrest, particularly G2/M phase, might be a useful therapy to prevent the proliferation of cancer cells [54]. The CDK1, Cyclin B and Cdc25C are essential for inducing $\mathrm{G} 2 / \mathrm{M}$ cycle phase, which could

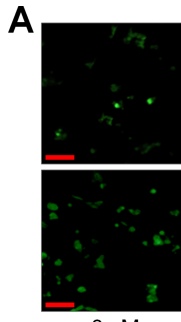

$0 \mathrm{uM}$
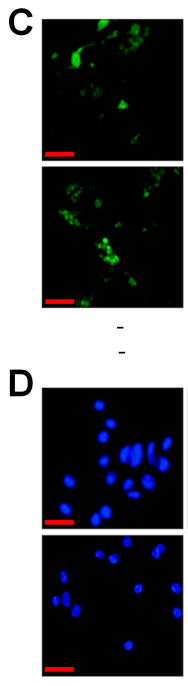

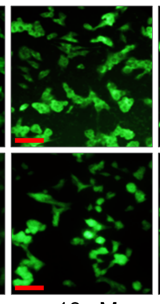

$10 \mathrm{uM}$
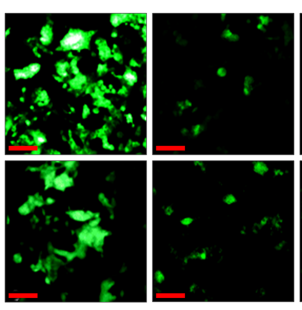

$+$
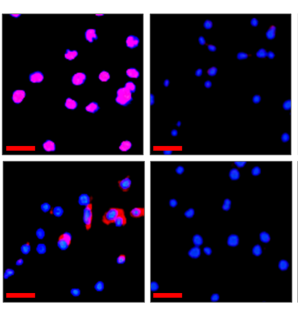

$+$
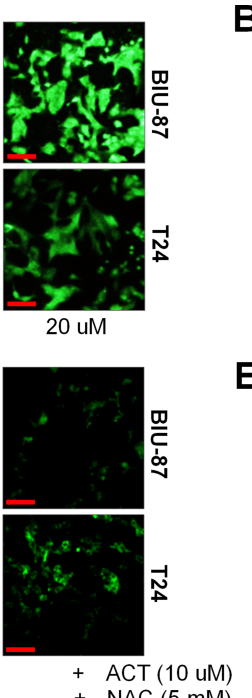

+ NAC (5 mM)

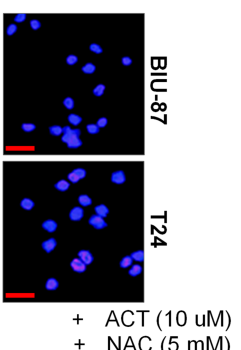

B
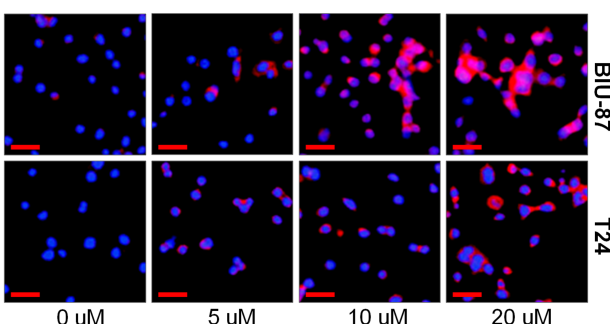

E

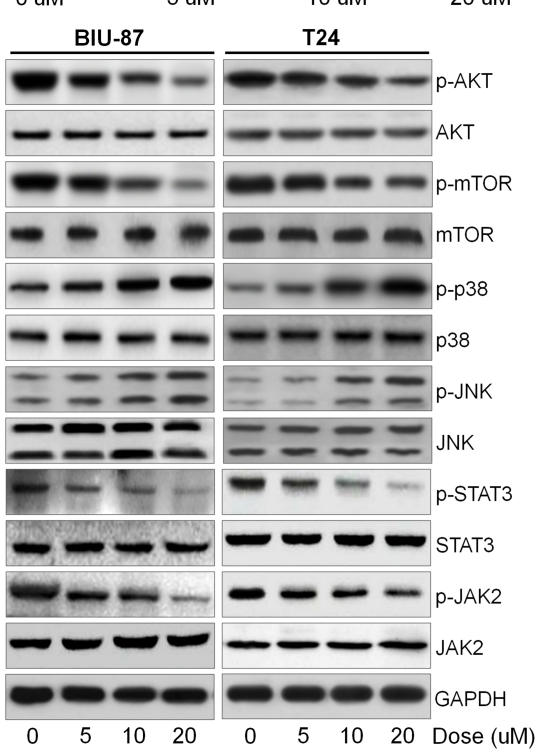

Figure 6: Actein potentiates ROS/JNK, and suppresses AKT pathway. (A) BIU-87 and T24 cells were treated with different doses of ACT for $24 \mathrm{~h}$, and then all cells were collected for DCF analysis to calculate the generation of ROS using fluorescent microscope. (B) BIU-87 and T24 cells were stained with MitoSOX Red after various treatments, and then the ROS levels were examined through confocal microscope. (C, D) The bladder cancer cells were pre-treated with ROS scavenger of NAC (5 mM) for $2 \mathrm{~h}$, and then all cells were subjected with or without ACT (10 uM) for another $24 \mathrm{~h}$, followed by DCF and MitoSOX Red staining using confocal microscope. (E) BIU-87 and T24 cells were treated with ACT for $24 \mathrm{~h}$, and then p-AKT, p-mTOR, p-p38, p-JNK, p-STAT3 and p-JAK2 protein levels were evaluated using western blot analysis. Data are represented as mean \pm S.E.M. 
enhance the dividing of a cell into two [55]. Our study indicated that ACT administration improved p-Cdk1, Cyclin B, p-Cdc25c, p53 and p21 expression, while reduced 14-3-3 $\sigma$ levels, which are vital signals involved in G2/M phase arrest induction. P21 plays an important role in suppressing Cdk1, Cyclin B, Cdk2 and Cyclin A activation, which might be relied on p53 expression [56]. The $\mathrm{p}-\mathrm{Cdc} 25 \mathrm{C}$ was occurred, which was an up-streaming signal of $\mathrm{Cdk} 1 / \mathrm{Cyclin} \mathrm{B}$, resulting in $\mathrm{G} 2 / \mathrm{M}$ phase arrest. And $\mathrm{Cdk} 2 / \mathrm{Cyclin} \mathrm{A}$ induced G1/S phase cycle [57]. Both G2/M and G1/S phase cycle arrest are hallmarks of DNA damage checkpoints [58]. Decreased p-Cdk2 and Cyclin A were observed in ACT-treated bladder cancer cells. Thus, ACT triggered G2/M arrest and disturbance of G1/S were possibly associated with the improvement of $\mathrm{p}-\mathrm{Cdk} 1$, Cyclin B, p-Cdc25c, p53 and p21, as well as the reduction of p-Cdk2 and Cyclin A.
Autophagy plays an important role in determining the cell condition [23]. Autophagic flux is the complete mechanism of autophagy originating with the fusion of the autophagosome with a lysosome, resulting in degradation and recycling of the cargo [30-32]. LC3 is necessary during proteolytic processing, yielding a $16-\mathrm{kDa}$ LC3-I protein that conjugates with phosphatidyl ethanolamine to yield a 14-kDa LC3-II form, in which LC3-II is used as a marker of complete activation of autophagosome $[43,59,60]$. The p62 protein is involved in the lysosomedependent degradation system that directly interacts with LC3-II and degradation in the process of autophagy, and suppression of autophagy results in enhanced $\mathrm{p} 62$ protein levels $[44,61]$. Accumulating evidence suggested the dual effect of autophagy on cancer, contributing to cell death or protecting cell survival [31, 33-35]. In our study, we found that ACT induced autophagy dose-dependently, which
A

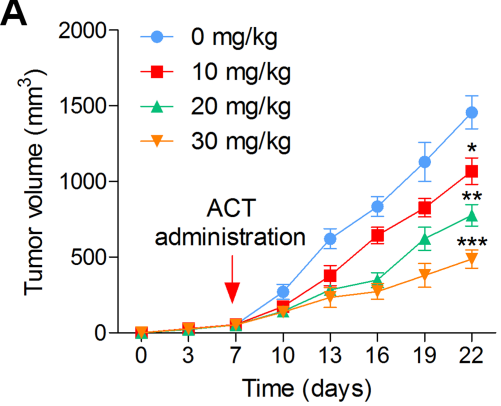

B

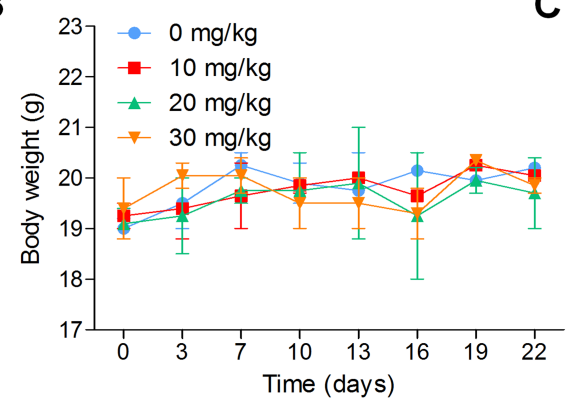

E

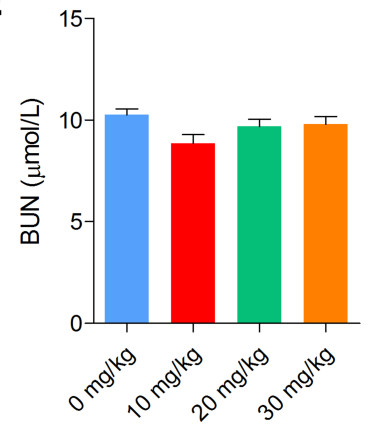

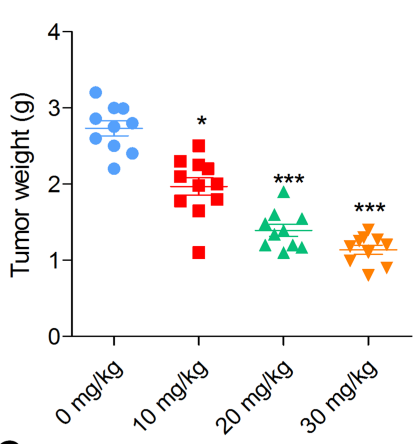

C

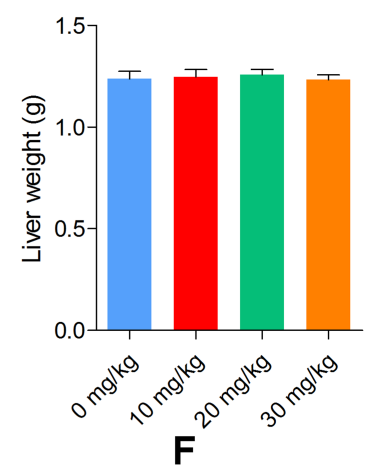

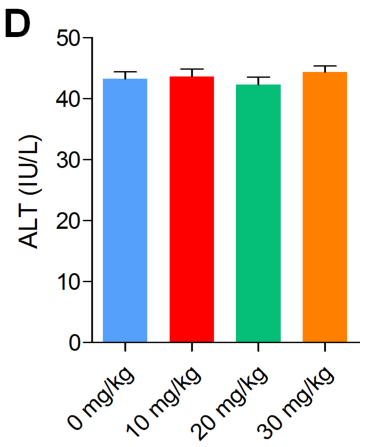

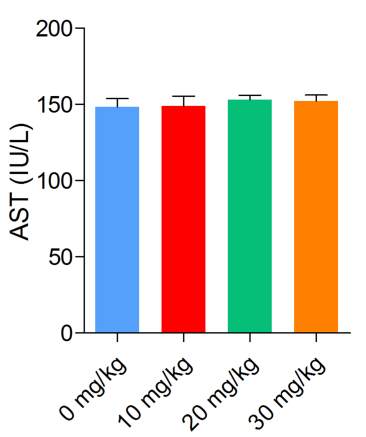

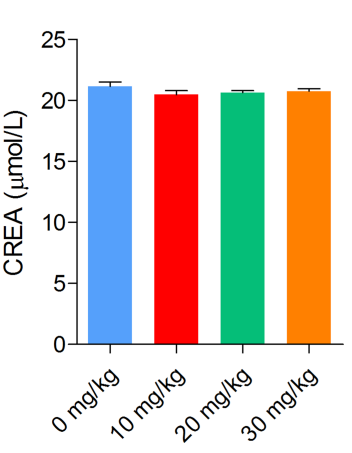

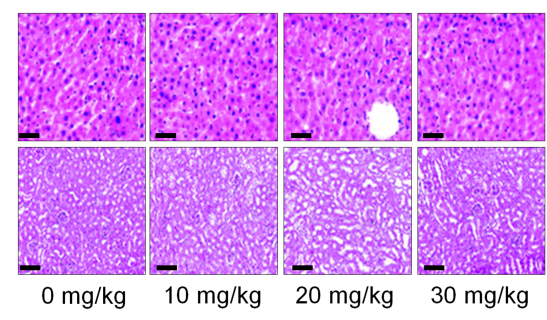

Figure 7: Actein inhibits the growth of human bladder xenograft mice in vivo. $2 \times 10^{5}$ BIU-87 cells were subcutaneously inoculated into nude mice. When tumors were obvious (tumor size about $50 \mathrm{~mm}^{3}$ ), mice were randomly grouped to receive 10,20 and 30 $\mathrm{mg} / \mathrm{kg}$ ACT for 15 days. (A) Tumor volume and tumor weight were measured. (B, C) The body weight and liver weight were examined. (D) The ALT and AST levels in plasma were determined to evaluate the hepatic toxicity. (E) The renal toxicity was calculated through measuring serum BUN and CREA levels in mice. (F) H\&E staining of liver and kidney isolated from mice. Data are represented as mean \pm S.E.M. ${ }^{*} p<0.05,{ }^{* *} p<0.01,{ }^{* * *} p<0.001$ versus the untreated group. 
was proved by the accumulation of autophagic vesicles and improvement of LC3B-I/II and Beclin 1, as well as reduction of p62. In addition, an autophagy inhibitor of 3-MA was used in our study, and 3-MA could accelerate the suppressive effects of ACT on the bladder cancer cell viability, indicating that ACT-triggered autophagy might be pro-survival.

Apoptosis is defined as programmed cell death PCD, executed by a family of cysteinyl aspartate proteinases known as Caspases [62]. Caspases are included in a family of highly conserved aspartate-specific cysteine proteases, which are expressed as inactive zymogens in animal cells as well as serve as the essential executioners of apoptosis $[63,64]$. When death receptors are stimulated, the extrinsic pathway, involved in the activation of Caspase-8, is initiated. The intrinsic pathway includes the activation of caspase- 9 , and this process is regulated by B-cell lymphoma-2 (Bcl-2) family proteins, including the anti-apoptotic signals of Bcl-2 and $\mathrm{Mcl}-1$, and the proapoptotic molecules of Bax, Bad and Bim [65, 66]. Once Caspases-3 is activated, it cleaves death substrates or a variety of proteins. During apoptosis, Caspase-3 cleaves PARP, decreasing its DNA repair activity and contributing to apoptotic cell death $[62,67]$. Our results indicated that mitochondrial membrane potential was significantly decreased for ACT exposure. Mitochondrial membrane depolarization could result in the release of cytochrome c and activate Caspase-9. We also found that Caspase-3, PARP, Caspase- 8 and Caspase- 9 were highly cleaved due to ACT administration, accompanied with reduced Bcl-2 and Mcl-1 as well as elevated Bax, Bad and Bim expressions, suggesting that ACT-induced apoptosis was Caspases-dependent.

ROS generation has been reported to be important in regulating autophagy and apoptosis [41, 68]. Consistently, in our study ROS production was highly induced by ACT, which was involved in ACT-triggered autophagy and apoptosis. Additionally, ACT-caused high expression of cleavage of Caspase-3, PARP, Caspase-8, and Caspase- 9 were significantly reversed by NAC, a ROS scavenger. Similarly, autophagy-related LC3BI/ II and Beclin 1 expressions were abolished by NAC in ACT-treated bladder cancer cells. The findings here suggested that ACT-induced autophagy and apoptosis was dependent on ROS production. Recently, mitogenactivated protein kinases (MAPK s), and PI3K/AKT signaling pathways are closely involved in autophagy and apoptosis progression $[69,70]$. JNK, and p38, main groups of MAPKs family, modulate a large number of cellular processes, including autophagy and apoptosis. P38 and JNK activity could positively induce apoptosis and autophagy [71]. In contrast, PI3K/AKT pathway was suggested to negatively modulate autophagy progression via controlling the mTOR phosphorylation [72, 73]. Further, JAK2/STAT3 signaling pathway is involved in the sustaining of self-renewal and tumorigenicity, which is constitutively phosphorylated in cancer cells $[74,75]$. In our present study, ACT dramatically activated p38 and JNK phosphorylation, whereas inactivated AKT/mTOR and JAK2/STAT3 signaling pathways. Additionally, the relationship between JNK and AKT/mTOR with autophagy and apoptosis induced by ACT was further explored. The findings indicated that inhibiting the activity of JNK greatly eliminated cleaved Caspase-3, PARP, Caspase-8, and Caspase-9, as well as LC3BI/II and Beclin 1 , which was induced by ACT. In contrast, inhibition of AKT and mTOR activation strengthened apoptosis- and autophagy-related signals expression. Thus, autophagy and apoptosis induced by ACT could be modulated by ROS/JNK, and AKT/mTOR pathways.

In vivo, ACT could inhibit the bladder tumor growth. And ALT, AST, BUN, and CREA showed no significant difference among various groups of mice, indicating that ACT at the concentrations used in our study, showed no hepatic and renal toxicity. And H\&E staining of liver and kidney further confirmed the safety of ACT for application. Moreover, TUNEL assays indicated that apoptosis was induced by ACT in vivo. And western blot analysis illustrated that cleavage of Caspase-3, PARP, Caspase-8, and Caspase- 9 were significantly induced by $\mathrm{ACT}$, and LC3B-I/II and Beclin 1 were also potentiated due to ACT treatment in tumor samples.

Together, our findings exhibited that ACT inhibited the cell proliferation, induced autophagy and apoptosis that were dependent on ROS/JNK activity, and AKT inactivity in human bladder cancer cells. Inhibiting autophagy potentiated ACT-triggered cell death and apoptosis, revealing that autophagy induced by ACT was a pro-survival procedure. The working model of ACT in suppressing human bladder cancer development was exhibited in Figure 8C. In conclusion, our study indicated that ACT might be a promising candidate against human bladder cancer development.

\section{MATERIALS AND METHODS}

\section{Materials}

3-(4,5-dimethyl-2-thiazolyl)-2,5-diphenyl-2Htetrazolium bromide (MTT) were purchased from the Sigma Chemical Company (St. Louis, MO). The primary antibody of GAPDH (dilution: 1:200) was purchased from Santa Cruz Biotechnology (USA). p53, p21, p-Cdk1, Cyclin B, p-Cdc25C, 14-3-36, p-Cdk2, Cyclin A, LC3B, p62, Beclin 1, PARP, Bcl-2, Mcl-1, Caspase-9, Caspase-8, Caspase-3, Bax, Bim, p-STAT3, STAT3, p-JAK2 and JAK2 were purchased from Abcam (dilution: 1:1000, USA). Bad, p-p38, p38, p-AKT, AKT, p-mTOR, mTOR, JNK and p-JNK were obtained from Cell Signaling Technology (dilution: 1:1000, USA). The secondary horseradish peroxidase (HRP)-conjugated antibodies were purchased from Jackson ImmunoResearch (West Grove, 
PA, USA). Actein was purchased from ChromaDex (Laguna Hills, CA), which was purified by highperformance liquid chromatography (HPLC). Annexin V-FITC/PI Detection kit was obtained from BioVision (CA, USA). Alanine aminotransferase (ALT) Assay Kit, Aspartate aminotransferase (AST) Assay Kit, Urea (BUN) Assay Kit and Creatinine (Cr) Assay kit were purchased from Nanjing Jiancheng Bioengineering Institute (Nanjing, China). Dimethyl sulfoxide (DMSO) was obtained from Sigma-Aldrich Chemical Company. The enhanced chemiluminescence (ECL) and bicinchoninic acid (BCA) were purchased from Thermo Fisher Scientific (San Diego, CA, USA). The In situ BrdU-Red DNA Fragmentation (TUNEL) Assay Kit was purchased from Abcam. Annexin V/PI Cell Apoptosis Detection Kit was obtained from KeyGen Biotech (Shanghai, China). Hoechst 33258 was purchased from Invitrogen (Carlsbad, CA). JC-10 Mitochondrial Membrane Potential Assay Kit (Microplate) and JC-1 Mitochondrial Membrane Potential Assay Kit were purchased from Abcam. Reactive Oxygen Species Assay Kit was obtained from KeyGen Biotech. ROS scavenger of NAC, JNK inhibitor of SP600125, autophagy suppressor of 3-MA, and AKT inhibitor of MK2206 and
mTOR inhibitor of Rapamycin (RAPA) were purchased from Sigma Chemical Company. LysoTracker Red DND99 was purchased from Invitrogen (USA). One Step TUNEL Apoptosis Assay Kit was obtained from Beyotime.

\section{Cells and culture}

Human bladder cancer cell line, BIU-87, was purchased from American Type Culture Collection (ATCC, Manassas, VA, USA). Human bladder cancer cell lines of 5637 and T24, human urothelial cell line of SV-HUC-1 and human normal cell line of L-02 were purchased from the Cell Bank of the Chinese Academy of Sciences (Shanghai, China). BIU-87, 5637 and L-02 were maintained in RPMI-1640 medium (GibcoBRL, Grand Island, NY, USA) containing $10 \%(\mathrm{w} / \mathrm{v})$ fetal bovine serum in a humidified $\mathrm{CO}_{2}$ incubator under $5 \%$ $\mathrm{CO}_{2}$. SV-HUC-1 and T24 were cultured in F-12 medium (GibcoBRL). The cells were harvested in a $0.025 \%$ trypsin-EDTA (GibcoBRL) with phosphate buffered saline (PBS) solution, plated at the required cell number, and allowed to adhere before drug treatment. The cells were exposed to different doses of drugs for study.
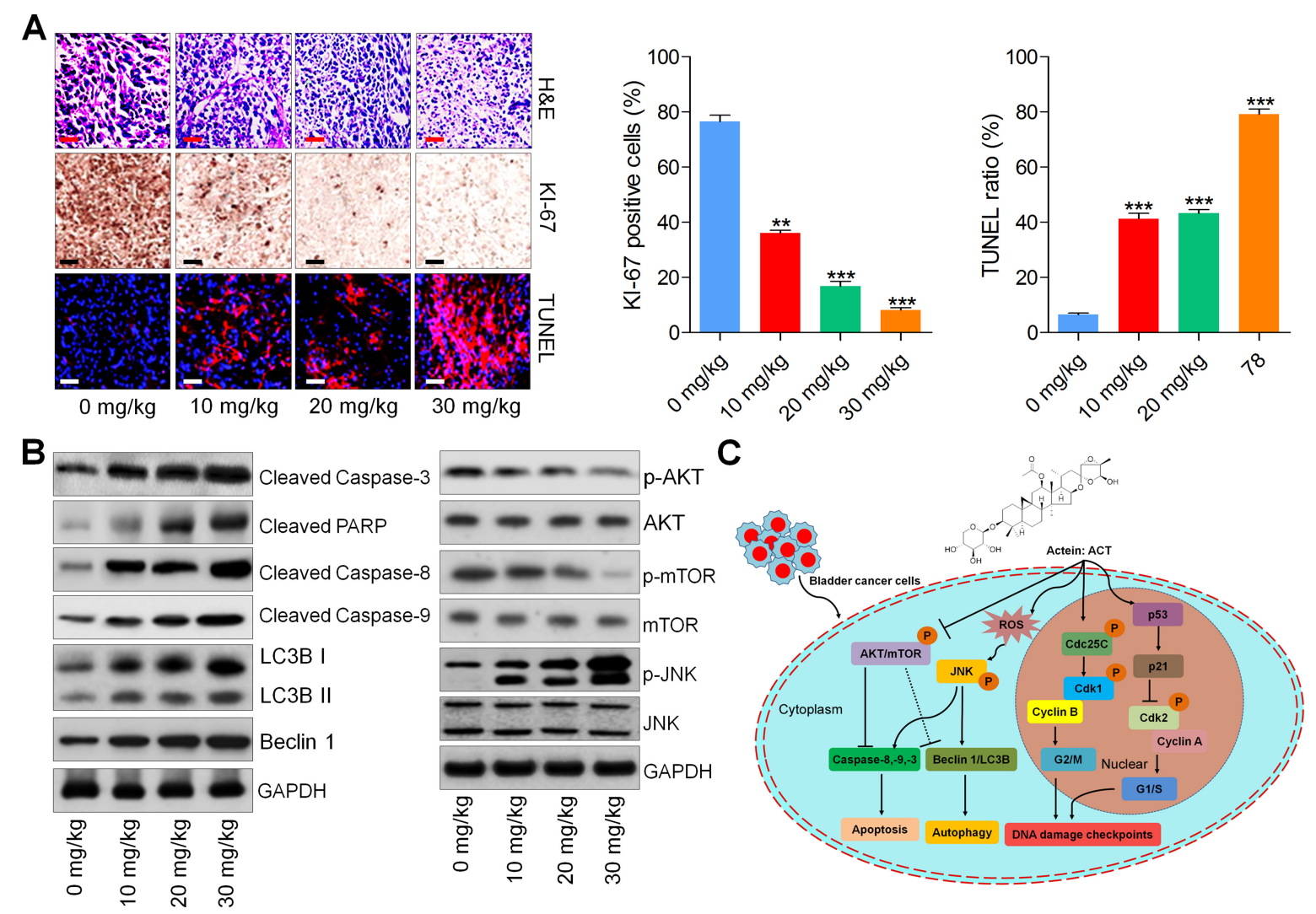

Figure 8: Actein-suppressed growth of human bladder xenograft mice is associated with induction of apoptosis and autophagy. (A) H\&E staining, KI-67 and TUNEL expression levels of tumor tissues were measured using IHC analysis. (B) Western blot analysis of Cleaved Caspase-3, PARP, Caspase-8, Caspase-9, LC3BI/II, Beclin 1, p-AKT, p-mTOR, and p-JNK in tumor tissue samples. (C) The proposed work model of ACT in suppressing human bladder cancer cells. ACT could inhibit cell proliferation through causing G2/M cell cycle arrest, and inducing apoptosis and autophagy by potentiating ROS and JNK activity, while inhibiting AKT pathway. Data are represented as mean \pm S.E.M. ${ }^{*} p<0.05,{ }^{* *} p<0.01,{ }^{* * *} p<0.001$ versus the untreated group. 


\section{Cell viability analysis}

MTT was used to calculate cell viability. $2 \times 10^{4}$ cells/well were seeded on 96-well plates and incubated at $37^{\circ} \mathrm{C}$ overnight under an atmosphere of $95 \%$ air and $5 \% \mathrm{CO}_{2}$, and then treated with various concentration of $\operatorname{ACT}(0,2.5,5,10,20$ and $40 \mathrm{uM})$ for $24 \mathrm{~h}$. MTT solution (300 $\mu \mathrm{L} /$ well) was added after incubation. Following incubation for an additional $4 \mathrm{~h}$ at $37^{\circ} \mathrm{C}$, the supernatants were removed and $200 \mu \mathrm{l}$ DMSO was added into each well to dissolve the formazan crystals. The 96-well plates were then placed in a microplate reader (Bio-Tek, USA) to assess the absorbance at $490 \mathrm{~nm}$. Each test performed in triplicate.

\section{Colony formation assays}

1000 cells, BIU-87 and T24, were planted into a $35-\mathrm{mm}$ petri dish to adhere overnight. Following, a different ACT treatment was performed to the dishes for $24 \mathrm{~h}$, after which the medium was replaced with drug-free medium. Cells were further cultured for two weeks to allow colonies formation. Next, the colonies were fixed with paraformaldehyde (4\%) and then stained with crystal violet solution $(0.1 \%)$, and washed, and imaged finally. The number of colonies larger than $0.5 \mathrm{~mm}$ in diameter was counted using a microscope (Nikon, Japan) at $400 \times$ magnification.

\section{Flow cytometry analysis}

The cells were harvested after treatment with ACT as indicated and stained with the Annexin V/PI Cell Apoptosis Detection Kit following the manufacturer's instructions. The cells in early stages of apoptosis were Annexin V positive and PI negative, and the cells in the late stages of apoptosis were both Annexin V and PI positive. The results acquisition and analysis were carried out with a Becton Dickinson FACS Calibur flow cytometer using Cell-Quest software (Becton Dickinson).

The effect of ACT, NAC, SP600125, MK2206 and RAPA treatment on cell cycle distribution was also measured using flow cytometry analysis. After treatment under various conditions, all cells were harvested and fixed in ethanol $(70 \%)$. The cells were then rinsed with PBS for twice and stained with PI solution containing PI $(50 \mu \mathrm{g} / \mathrm{mL})$ and RNAse $(25 \mu \mathrm{g} / \mathrm{mL})$ for $30 \mathrm{~min}$. In the end, cells were analyzed on a FACS Calibur flow cytometer and analyzed with Cell-Quest Pro software.

\section{TUNEL assays in vitro}

The bladder cancer cells were exposed to ACT administration for $24 \mathrm{~h}$ on 12-well plates. Then, One Step TUNEL Apoptosis Assay Kit was used to evaluate apoptosis following the manufacturer's instructions.
Nuclei were stained with 4',6-diamidino-2-phenylindole (DAPI). The staining intensity was measured by a fluorescence microscopy.

\section{Hoechst 33258 analysis}

The bladder cancer cells after ACT administration for $24 \mathrm{~h}$ on 12 -well plates were then stained with $10 \mu \mathrm{g} / \mathrm{ml}$ of Hoechst 33258 in $1 \mathrm{ml}$ PBS for 30 min. Hoechst 33258 was applied for nuclei staining of cells. After staining, samples were rinsed with PBS once and $1 \mathrm{ml}$ of PBS was added. The representative images of cells were captured using a fluorescence microscopy.

\section{Mitochondrial potential assessment}

JC-1 and JC-10 dye loading solutions were added to BIU-87 and T24 cells after treatment as indicated and incubated for 30 minutes. The fluorescent intensities for both J-aggregates and monomeric forms of JC- 1 and JC10 were measured at $\mathrm{Ex} / \mathrm{Em}=490 / 525 \mathrm{~nm}$ and $490 / 590$ $\mathrm{nm}$ with a microplate reader (Biotek, Winooski, VT).

\section{Western blot analysis}

Human bladder cancer cells after different treatments were harvested and washed with chilled PBS and harvested in sample buffer $(150 \mathrm{mM} \mathrm{NaCl}, 100 \mathrm{mM}$ $\mathrm{NaF}, 50 \mathrm{mM}$ Tris- $\mathrm{HCl}$ (pH 7.6), 0.5\% Nonidet P-40 (NP$40)$ and $1 \mathrm{mM}$ PMSF). And the bladder tumors were homogenized into $10 \%(\mathrm{wt} / \mathrm{vol})$ hypotonic buffer $(\mathrm{pH} 8.0$, $1 \mathrm{mM}$ EDTA, $5 \mu \mathrm{g} / \mathrm{ml}$ leupeptin, $25 \mathrm{mM}$ Tris-HCl, $1 \mathrm{mM}$ Pefabloc SC, $5 \mu \mathrm{g} / \mathrm{ml}$ soybean trypsin inhibitor, $50 \mu \mathrm{g} /$ $\mathrm{ml}$ aprotinin, $4 \mathrm{mM}$ benzamidine) to yield a homogenate. Then, the final supernatants from cells and tumors were obtained by centrifugation at $14,000 \times \mathrm{g}$ for $20 \mathrm{~min}$ at $4^{\circ} \mathrm{C}$. Protein concentration was determined using BCA protein assay kit with bovine serum albumin as a standard. Sample-loading buffer was added, the mixture was boiled for $5 \mathrm{~min}$. And the total protein extract are used for Western blot analysis. $40 \mu \mathrm{g}$ of total protein was loaded and proteins were separated using 10\% SDS-PAGE and electrophoretically transferred to the polyvinylidene difluoride membranes (Millipore, USA). The membranes were then blocked with 5\% skim milk Tris buffered saline with $0.1 \%$ Tween 20 (TBST), washed, and then incubated with primary antibody overnight at $4{ }^{\circ} \mathrm{C}$. Then, the membrane was washed with TBST for three times, followed by incubation with a horseradish peroxidase (HRP)-conjugated secondary antibody (1:2500) at room temperature for $2 \mathrm{~h}$. Following another round of washing with TBST, the membrane was then developed using ECL, and exposed to Kodak (Eastman Kodak Company, USA) X-ray film. Every protein expression levels will be defined as grey value using ImageJ 1.38 software (National Institutes of Health, USA) and standardized to 
housekeeping gene of GAPDH and expressed as a fold of control. All experiments were performed in triplicate and done three times independently.

\section{Measurement of ROS generation}

Intracellular ROS production was measured using the Reactive Oxygen Species Assay Kit. The bladder cancer cells were plated in six-well plates at a density of $5 \times 10^{5} / \mathrm{ml}$ and exposed to ACT and NAC, or the two in combination as indicated in each part. Cells were then stained with DCFH-DA $(10 \mu \mathrm{M})$ in the dark room for 30 min at $37^{\circ} \mathrm{C}$. Next, the cells were rinsed with serum-free DMEM three times, and the level of ROS generation was detected using fluorescence microscopy.

\section{LysoTracker red assays}

$5 \times 10^{5} / \mathrm{ml}$ bladder cancer cells were seeded in sixwell plates and treated with ACT and NAC, or the two in combination as indicated for $24 \mathrm{~h}$. Cells were then incubated with LysoTracker Red DND-99 $(50 \mathrm{nM})$ in the dark room at $37^{\circ} \mathrm{C}$ for $30 \mathrm{~min}$. Finally, the immunofluorescence images were captured using a confocal microscope.

\section{Transmission electron microscopy (TEM) analysis}

After different treatments with ACT as indicated for $24 \mathrm{~h}$, the cells were collected and washed with PBS then fixed in $2.5 \%$ glutaraldehyde overnight. Then, the cells were washed by PBS $(0.1 \mathrm{M})$ and fixed with OsO4 (1\%). Following, the cancer cells were dehydrated with a range of alcohol concentrations for 15 minutes. The cells were then embedded into paraffin and sliced using an LKB-V ultramicrotome (LKB, Stockholm, Sweden). For TEM images acquisition, the prepared sections were observed on a JEM-2100 microscope operating at microscope at an accelerating voltage of $200 \mathrm{kV}$ (JEOL Ltd., Tokyo, Japan).

\section{GFP-LC3 puncta analysis}

In order to calculate the formation of fluorescence puncta of autophagosomes, BIU-87 and T24 cells were transfected with GFP-LC3 plasmid. Then, all cells were cultured with $0,5,10$ and $20 \mu \mathrm{M}$ ACT for $24 \mathrm{~h}$. Next, the cells were rinsed with PBS twice, fixed with $4 \%$ paraformaldehyde for $20 \mathrm{~min}$, and permeabilized with $0.1 \%$ Triton X-100. Finally, the representative images were obtained using a fluorescent microscope.

\section{Human bladder cancer xenograft experiment}

4-week-old, female, BALB/c athymic nude mice (nu/nu) were purchased from Shanghai Slac Laboratory Animal Company Limited (Shanghai, China). Mouse care and usage were performed following the local ethical guidelines. The mice were raised in air-conditioned pathogen-free rooms under controlled lighting (12 h light/ day) and fed with water and standard laboratory food. All protocols were in accordance with the Regulations of Experimental Animal Administration issued by the Ministry of Science and Technology of the People's Republic of China. The animal study was carried out in accordance with the regulations of The Fourth Military Medical University (Xian, Shanxi, China). After 1 week's acclimation, single-tumor cell suspensions (BIU-87, $2 \times$ $10^{5}$ ) were subcutaneously injected into the left flank of each mouse to obtain bladder cancer xenografts. The mice were divided into four groups (15 mice/group) 7 days after cell implantation. Mice in the experimental groups were intraperitoneally injected with ACT at a dose of 0 , 10,20 and $30 \mathrm{mg} / \mathrm{kg}$ body weight per day. Mice in the control group received an equal volume of normal saline. The tumor volume was calculated every two days by two cross-sectional measurements, and the tumor size was measured as followings: tumor volume $=$ width $^{2} \times$ length $\times 0.4$. Mice were sacrificed after 22 days, and the tumors were weighed and then fixed in $10 \%$ formalin for the following experiments. The blood of each mouse was extracted through eyeballs and the serum was separated by centrifuge at $3,000 \times \mathrm{g}$ for $15 \mathrm{~min}$. Then, the activities of ALT, AST, BUN and CREA in serum were evaluated following the manufacturer's protocol. At the end of the experiment, all rest of mice were sacrificed. The liver, and renal tissues were excised, weighed, and fixed in $10 \%$ formalin for histology analysis.

\section{Immunohistochemical analysis}

Formalin-fixed tissue samples were embedded in $4 \%$ paraffin and then the paraffin-embedded specimens were cut into serial sections ( $3-\mu \mathrm{m}$ thickness). Primary tumors, liver, lung, and renal sections were stained with hematoxylin and erosion (H\&E). Mouse bladder tumors were sectioned at $3 \mu \mathrm{m}$ thickness, and stained with KI-67 (Abcam, 1:200). The tumor sections were analyzed using a microscope. Images were arranged through TissueFAXs (Tissue-Gnostics) software. The percentage of KI-67positive cells in each tumor section was quantified using the HistoQuest software. The number of KI-67positive cells was divided by the total number of cells in each tumor section. The apoptosis of tumor tissues was evaluated using TUNEL assay with the In situ Apoptosis Detection Kit following the manufacture's protocol. After deparaffinization and hydration, tumor tissue sections were washed with PBS twice and then incubated with proteinase $\mathrm{K}\left(20 \mu \mathrm{g} / \mathrm{ml}\right.$, Abcam) for $25 \mathrm{~min}$ at $37^{\circ} \mathrm{C}$, followed by washes with PBS. Then, all sections were incubated with TUNEL mixture. The tumor sections were counter-stained with DAPI. Finally, the tissue sections were observed with a confocal microscopy. 


\section{Statistical analysis}

Results are expressed as the mean \pm SEM of triplicate experiments. Statistically significant values were compared using the ANOVA and the Dunnett's post-hoc test, and $P$-values of $<0.05$ were considered to indicate a statistically significant result.

\section{CONFLICTS OF INTEREST}

None.

\section{REFERENCES}

1. Oršolić N, Karač I, Sirovina D, Kukolj M, Kunštić M, Gajski G, Garaj-Vrhovac V, Stajcar D. Chemotherapeutic potential of quercetin on human bladder cancer cells. J Environ Sci Health A Tox Hazard Subst Environ Eng. 2016; 51:776-81. https://doi.org/10.1080/10934529.2016.1170465.

2. Lorenzatti Hiles G, Bucheit A, Rubin JR, Hayward A, Cates AL, Day KC, El-Sawy L, Kunju LP, Daignault S, Lee CT, Liebert M, Hussain M, Day ML. ADAM15 Is Functionally Associated with the Metastatic Progression of Human Bladder Cancer. PLoS One. 2016; 11:e0150138. https://doi. org/10.1371/journal.pone.0150138.

3. Oršolić N, Karač I, Sirovina D, Kukolj M, Kunštić M, Gajski G, Garaj-Vrhovac V, Štajcar D. Chemotherapeutic potential of quercetin on human bladder cancer cells. J Environ Sci Health A Tox Hazard Subst Environ Eng. 2016; 51:776-81. https://doi.org/10.1080/10934529.2016.1170465.

4. Wang YW, Chuang JJ, Chang TY, Won SJ, Tsai HW, Lee CT, Cheng HL, Tzai TS, Liu HS, Chow NH. Antiangiogenesis as the novel mechanism for justicidin A in the anticancer effect on human bladder cancer. Anticancer Drugs. 2015; 26:42836. https://doi.org/10.1097/CAD.0000000000000203.

5. Hojeij R, Domingos-Pereira S, Nkosi M, Gharbi D, Derré L, Schiller JT, Jichlinski P, Nardelli-Haefliger D. Immunogenic Human Papillomavirus Pseudovirus-Mediated SuicideGene Therapy for Bladder Cancer. Int J Mol Sci. 2016; 17: E1125. https://doi.org/10.3390/ijms17071125.

6. Zhang S, Li J, Zhou G, Mu D, Yan J, Xing J, Yao Z, Sheng H, Li D, Lv C, Sun B, Hong Q, Guo H. Increased expression of ESCO1 is correlated with poor patient survival and its role in human bladder cancer. Tumour Biol. 2016; 37:516570. https://doi.org/10.1007/s13277-015-4375-1.

7. Einbond LS, Soffritti M, Esposti DD, Park T, Cruz E, Su T, Wu HA, Wang X, Zhang YJ, Ham J, Goldberg IJ, Kronenberg F, Vladimirova A. Actein activates stress- and statin-associated responses and is bioavailable in SpragueDawley rats. Fundam Clin Pharmacol. 2009; 23:311-21. https://doi.org/10.1111/j.1472-8206.2009.00673.x.

8. Einbond LS, Mighty J, Redenti S, Wu HA. Actein induces calcium release in human breast cancer cells. Fitoterapia. 2013; 91:28-38. https://doi.org/10.1016/j. fitote.2013.07.025.
9. Suh KS, Chon S, Choi EM. Actein protects against methylglyoxal-induced oxidative damage in osteoblastic MC3T3-E1 cells. J Sci Food Agric. 2017; 97:207-14. https://doi.org/10.1002/jsfa.7713.

10. Yang ZC, Ma J. Actein enhances TRAIL effects on suppressing gastric cancer progression by activating p53/ Caspase-3 signaling. Biochem Biophys Res Commun. 2016.

11. Henneicke-von Zepelin HH, Meden H, Kostev K, SchröderBernhardi D, Stammwitz U, Becher H. Isopropanolic black cohosh extract and recurrence-free survival after breast cancer. Int J Clin Pharmacol Ther. 2007; 45:143-54. https:// doi.org/10.5414/CPP45143.

12. Jiang B, Kronenberg F, Nuntanakorn P, Qiu MH, Kennelly EJ. Evaluation of the botanical authenticity and phytochemical profile of black cohosh products by highperformance liquid chromatography with selected ion monitoring liquid chromatography-mass spectrometry. J Agric Food Chem. 2006; 54:3242-53. https://doi. org/10.1021/jf0606149.

13. Chen SN, Li W, Fabricant DS, Santarsiero BD, Mesecar A, Fitzloff JF, Fong HH, Farnsworth NR. Isolation, structure elucidation, and absolute configuration of 26-deoxyactein from Cimicifuga racemosa and clarification of nomenclature associated with 27-deoxyactein. J Nat Prod. 2002; 65:60105. https://doi.org/10.1021/np010494t.

14. Watanabe K, Mimaki Y, Sakagami H, Sashida Y. Cycloartane glycosides from the rhizomes of Cimicifuga racemosa and their cytotoxic activities. Chem Pharm Bull (Tokyo). 2002; 50:121-25. https://doi.org/10.1248/ cpb.50.121.

15. Einbond LS, Shimizu M, Xiao D, Nuntanakorn P, Lim JT, Suzui M, Seter C, Pertel T, Kennelly EJ, Kronenberg F, Weinstein IB. Growth inhibitory activity of extracts and purified components of black cohosh on human breast cancer cells. Breast Cancer Res Treat. 2004; 83:221-31. https://doi.org/10.1023/B:BREA.0000014043.56230.a3.

16. Tian Z, Si J, Chang Q, Zhou L, Chen S, Xiao P, Wu E. Antitumor activity and mechanisms of action of total glycosides from aerial part of Cimicifuga dahurica targeted against hepatoma. BMC Cancer. 2007; 7:237. https://doi. org/10.1186/1471-2407-7-237.

17. Wu D, Yao Q, Chen Y, Hu X, Qing C, Qiu M. The in Vitro and in Vivo Antitumor Activities of Tetracyclic Triterpenoids Compounds Actein and 26-Deoxyactein Isolated from Rhizome of Cimicifuga foetida L. Molecules. 2016; 21:1001. https://doi.org/10.3390/molecules21081001.

18. Xi R, Wang LJ. Actein ameliorates hepatobiliary cancer through stemness and p53 signaling regulation. Biomed Pharmacother. 2017; 88:242-51. https://doi.org/10.1016/j. biopha.2017.01.038.

19. Risal S, Adhikari D, Liu K. Animal Models for Studying the In Vivo Functions of Cell Cycle CDKs. Methods Mol Biol. 2016; 1336:155-66. https://doi.org/10.1007/978-1-49392926-9_13. 
20. Simmons Kovacs LA, Orlando DA, Haase SB. Transcription networks and cyclin/CDKs: the yin and yang of cell cycle oscillators. Cell Cycle. 2008; 7:2626-29. https://doi. org/10.4161/cc.7.17.6515.

21. Hsiao YC, Hsieh YS, Kuo WH, Chiou HL, Yang SF, Chiang WL, Chu SC. The tumor-growth inhibitory activity of flavanone and 2'-OH flavanone in vitro and in vivo through induction of cell cycle arrest and suppression of cyclins and CDKs. J Biomed Sci. 2007; 14:107-19. https://doi. org/10.1007/s11373-006-9117-3.

22. Sánchez I, Dynlacht BD. New insights into cyclins, CDKs, and cell cycle control. Semin Cell Dev Biol. 2005; 16:31121. https://doi.org/10.1016/j.semcdb.2005.02.007.

23. Lim S, Kaldis P. Cdks, cyclins and CKIs: roles beyond cell cycle regulation. Development. 2013; 140:3079-93. https:// doi.org/10.1242/dev.091744.

24. Malumbres M, Barbacid M. Cell cycle, CDKs and cancer: a changing paradigm. Nat Rev Cancer. 2009; 9:153-66. https://doi.org/10.1038/nrc2602.

25. Gubern A, Joaquin M, Marquès $M$, Maseres $P$, GarciaGarcia J, Amat R, González-Nuñez D, Oliva B, Real FX, de Nadal E, Posas F. The N-Terminal Phosphorylation of RB by p38 Bypasses Its Inactivation by CDKs and Prevents Proliferation in Cancer Cells. Mol Cell. 2016; 64:25-36. https://doi.org/10.1016/j.molcel.2016.08.015.

26. Fischer M, Quaas M, Nickel A, Engeland K. Indirect p53dependent transcriptional repression of Survivin, CDC25C, and PLK1 genes requires the cyclin-dependent kinase inhibitor p21/CDKN1A and CDE/CHR promoter sites binding the DREAM complex. Oncotarget. 2015; 6:4140217. https://doi.org/10.18632/oncotarget.6356.

27. Wu G, Lin N, Xu L, Liu B, Feitelson MA. UCN-01 induces $\mathrm{S}$ and $\mathrm{G} 2 / \mathrm{M}$ cell cycle arrest through the p53/p21(waf1) or CHK2/CDC25C pathways and can suppress invasion in human hepatoma cell lines. BMC Cancer. 2013; 13:167. https://doi.org/10.1186/1471-2407-13-167.

28. Wu G, Lin N, Xu L, Liu B, Feitelson MA. UCN-01 induces $\mathrm{S}$ and $\mathrm{G} 2 / \mathrm{M}$ cell cycle arrest through the p53/p21(waf1) or $\mathrm{CHK} 2 / \mathrm{CDC} 25 \mathrm{C}$ pathways and can suppress invasion in human hepatoma cell lines. BMC Cancer. 2013; 13:167. https://doi.org/10.1186/1471-2407-13-167.

29. Xiong L, Liu Z, Ouyang G, Lin L, Huang H, Kang H, Chen W, Miao X, Wen Y. Autophagy inhibition enhances photocytotoxicity of Photosan-II in human colorectal cancer cells. Oncotarget. 2017; 8:6419-32. https://doi. org/10.18632/oncotarget.14117.

30. Wu Y, Ni Z, Yan X, Dai X, Hu C, Zheng Y, He F, Lian J. Targeting the MIR34C-5p-ATG4B-autophagy axis enhances the sensitivity of cervical cancer cells to pirarubicin. Autophagy. 2016; 12:1105-17. https://doi.org/10.1080/155 48627.2016.1173798.

31. Xiao W, Dai B, Zhu Y, Ye D. Norcantharidin induces autophagy-related prostate cancer cell death through Beclin-1 upregulation by miR-129-5p suppression. Tumour Biol. 2015.
32. Xu DW, Zhang GQ, Wang ZW, Xu XY, Liu TX. Autophagy in tumorigenesis and cancer treatment. Asian Pac J Cancer Prev. 2015; 16:2167-75. https://doi.org/10.7314/ APJCP.2015.16.6.2167.

33. Ishaq M, Khan MA, Sharma K, Sharma G, Dutta RK, Majumdar S. Gambogic acid induced oxidative stress dependent caspase activation regulates both apoptosis and autophagy by targeting various key molecules (NF- $\mathrm{kB}$, Beclin-1, p62 and NBR1) in human bladder cancer cells. Biochim Biophys Acta. 2014; 1840:3374-84. https://doi. org/10.1016/j.bbagen.2014.08.019.

34. Won SJ, Yen CH, Liu HS, Wu SY, Lan SH, Jiang-Shieh YF, Lin CN, Su CL. Justicidin A-induced autophagy flux enhances apoptosis of human colorectal cancer cells via class III PI3K and Atg5 pathway. J Cell Physiol. 2015; 230:930-46. https://doi.org/10.1002/jcp.24825.

35. Zhang Y, Fang F, Fan K, Zhang Y, Zhang J, Guo H, Yu P, Ma J. Effective cytotoxic activity of OSW-1 on colon cancer by inducing apoptosis in vitro and in vivo. Oncol Rep. 2017; 37:3509-19. https://doi.org/10.3892/or.2017.5582.

36. Ren SX, Shen J, Cheng AS, Lu L, Chan RL, Li ZJ, Wang XJ, Wong CC, Zhang L, Ng SS, Chan FL, Chan FK, Yu J, et al. Correction: FK-16 Derived from the Anticancer Peptide LL-37 Induces Caspase-Independent Apoptosis and Autophagic Cell Death in Colon Cancer Cells. PLoS One. 2015; 10:e0131750. https://doi.org/10.1371/journal. pone. 0131750 .

37. Hagen RM, Chedea VS, Mintoff CP, Bowler E, Morse HR, Ladomery MR. Epigallocatechin-3-gallate promotes apoptosis and expression of the caspase 9a splice variant in PC3 prostate cancer cells. Int J Oncol. 2013; 43:194-200. https://doi.org/10.3892/ijo.2013.1920.

38. Duan F, Yu Y, Guan R, Xu Z, Liang H, Hong L. Vitamin K2 Induces Mitochondria-Related Apoptosis in Human Bladder Cancer Cells via ROS and JNK/p38 MAPK Signal Pathways. PLoS One. 2016; 11:e0161886. https://doi. org/10.1371/journal.pone.0161886.

39. Lin $\mathrm{MH}$, Cheng $\mathrm{CH}$, Chen $\mathrm{KC}$, Lee WT, Wang YF, Xiao CQ, Lin CW. Induction of ROS-independent JNKactivation-mediated apoptosis by a novel coumarinderivative, DMAC, in human colon cancer cells. Chem Biol Interact. 2014; 218:42-49. https://doi.org/10.1016/j. cbi.2014.04.015.

40. Zhang $X$, Wang $X$, Wu T, Li B, Liu T, Wang R, Liu Q, Liu Z, Gong Y, Shao C. Isoliensinine induces apoptosis in triple-negative human breast cancer cells through ROS generation and p38 MAPK/JNK activation. Sci Rep. 2015; 5:12579. https://doi.org/10.1038/srep12579.

41. Zhu X, Wang K, Zhang K, Zhu L, Zhou F. Ziyuglycoside II induces cell cycle arrest and apoptosis through activation of ROS/JNK pathway in human breast cancer cells. Toxicol Lett. 2014; 227:65-73. https://doi.org/10.1016/j. toxlet.2014.03.015.

42. Chen K, Chu BZ, Liu F, Li B, Gao CM, Li LL, Sun QS, Shen ZF, Jiang YY. New benzimidazole acridine derivative 
induces human colon cancer cell apoptosis in vitro via the ROS-JNK signaling pathway. Acta Pharmacol Sin. 2015; 36:1074-84. https://doi.org/10.1038/aps.2015.44.

43. Huang AC, Lien JC, Lin MW, Yang JS, Wu PP, Chang SJ, Lai TY. Tetrandrine induces cell death in SAS human oral cancer cells through caspase activation-dependent apoptosis and LC3-I and LC3-II activation-dependent autophagy. Int J Oncol. 2013; 43:485-94. https://doi.org/10.3892/ijo.2013.1952.

44. Xie ZZ, Li MM, Deng PF, Wang S, Wang L, Lu XP, Hu LB, Chen Z, Jie HY, Wang YF, Liu XX, Liu Z. Paris saponininduced autophagy promotes breast cancer cell apoptosis via the Akt/mTOR signaling pathway. Chem Biol Interact. 2017; 264:1-9. https://doi.org/10.1016/j.cbi.2017.01.004.

45. Lei FR, Li XQ, Liu H, Zhu RD, Meng QY, Rong JJ. Rapamycin and 3-methyladenine regulate apoptosis and autophagy in bone-derived endothelial progenitor cells. Chin Med J (Engl). 2012; 125:4076-82.

46. O’Donnell JS, Massi D, Teng MW, Mandala M. PI3K-AKTmTOR inhibition in cancer immunotherapy, redux. Semin Cancer Biol. 2017.

47. Sun ZL, Dong JL, Wu J. Juglanin induces apoptosis and autophagy in human breast cancer progression via ROS/ JNK promotion. Biomed Pharmacother. 2017; 85:303-12. https://doi.org/10.1016/j.biopha.2016.11.030.

48. Wong CH, Iskandar KB, Yadav SK, Hirpara JL, Loh T, Pervaiz S. Correction: Simultaneous Induction of NonCanonical Autophagy and Apoptosis in Cancer Cells by ROS-Dependent ERK and JNK Activation. PLoS One. 2016; 11:e0159352. https://doi.org/10.1371/journal.pone.0159352.

49. Mazeron R, Dumas I, Rivin E, Martin V, BenhabibBoukhelif W, Tailleur A, Guemnie-Tafo A, Martinetti F, Chargari C, Lefkopoulos D, Haie-Meder C. D2 $\mathrm{cm}^{3} /$ DICRU ratio as a surrogate of bladder hotspots localizations during image-guided adaptive brachytherapy for cervical cancer: assessment and implications in late urinary morbidity analysis. Brachytherapy. 2015; 14:300-07. https://doi. org/10.1016/j.brachy.2014.10.005.

50. Hwang EC, Jung SI, Lee HJ, Lee JJ, Kwon DD. Generation of potent cytotoxic $\mathrm{T}$ lymphocytes against in male patients with non-muscle invasive bladder cancer by dendritic cells loaded with dying T24 bladder cancer cells. Int Braz J Urol. 2017; 43:615-27. https://doi.org/10.1590/s1677-5538. ibju.2016.0274.

51. Biers S, Sievert KD, Thiruchelvam N. Overactive bladder syndrome and lower urinary tract symptoms after prostate cancer treatment. Curr Opin Urol. 2017; 27:307-13. https:// doi.org/10.1097/MOU.0000000000000391.

52. Sánchez-Carranza JN, Alvarez L, Marquina-Bahena S, Salas-Vidal E, Cuevas V, Jiménez EW, Veloz G RA, Carraz M, González-Maya L. Phenolic Compounds Isolated from Caesalpinia coriaria Induce S and G2/M Phase Cell Cycle Arrest Differentially and Trigger Cell Death by Interfering with Microtubule Dynamics in Cancer Cell Lines. Molecules. 2017; 22:666. https://doi.org/10.3390/ molecules22040666.
53. Zhang J, Li S, Shang Z, Lin S, Gao P, Zhang Y, Hou S, Mo S, Cao W, Dong Z, Hu T, Chen P. Targeting the overexpressed ROC1 induces G2 cell cycle arrest and apoptosis in esophageal cancer cells. Oncotarget. 2017; 8:29125-37. https://doi.org/10.18632/oncotarget.16250.

54. Rao PC, Begum S, Sahai M, Sriram DS. Coptisine-induced cell cycle arrest at $\mathrm{G} 2 / \mathrm{M}$ phase and reactive oxygen speciesdependent mitochondria-mediated apoptosis in non-smallcell lung cancer A549 cells. Tumour Biol. 2017; 39:54. https://doi.org/10.1177/1010428317694565.

55. Kang N, Jian JF, Cao SJ, Zhang Q, Mao YW, Huang YY, Peng YF, Qiu F, Gao XM. Physalin A induces G2/M phase cell cycle arrest in human non-small cell lung cancer cells: involvement of the p38 MAPK/ROS pathway. Mol Cell Biochem. 2016; 415:145-55. https://doi.org/10.1007/ s11010-016-2686-1.

56. Chowdhury IH, Farhadi A, Wang XF, Robb ML, Birx DL, Kim JH. Human T-cell leukemia virus type 1 Tax activates cyclin-dependent kinase inhibitor p21/Waf1/ Cip1 expression through a p53-independent mechanism: inhibition of cdk2. Int J Cancer. 2003; 107:603-11. https:// doi.org/10.1002/ijc.11316.

57. Ming P, Cai T, Li J, Ning Y, Xie S, Tao T, Tang F. A novel arylbenzofuran induces cervical cancer cell apoptosis and G1/S arrest through ERK-mediated Cdk2/cyclin-A signaling pathway. Oncotarget. 2016; 7:41843-56. https:// doi.org/10.18632/oncotarget.9731.

58. Huang SY, Hsieh MJ, Chen CY, Chen YJ, Chen JY, Chen MR, Tsai CH, Lin SF, Hsu TY. Epstein-Barr virus Rta-mediated transactivation of p21 and 14-3-3 $\sigma$ arrests cells at the G1/S transition by reducing cyclin E/CDK2 activity. J Gen Virol. 2012; 93:139-49. https://doi.org/10.1099/vir.0.034405-0.

59. Cao QH, Liu F, Yang ZL, Fu XH, Yang ZH, Liu Q, Wang L, Wan XB, Fan XJ. Prognostic value of autophagy related proteins ULK1, Beclin 1, ATG3, ATG5, ATG7, ATG9, ATG10, ATG12, LC3B and p62/SQSTM1 in gastric cancer. Am J Transl Res. 2016; 8:3831-47.

60. Li WL, Xiong LX, Shi XY, Xiao L, Qi GY, Meng C. IKK $\beta /$ NFkBp65 activated by interleukin-13 targets the autophagyrelated genes LC3B and beclin 1 in fibroblasts co-cultured with breast cancer cells. Exp Ther Med. 2016; 11:1259-64. https://doi.org/10.3892/etm.2016.3054.

61. Moscat J, Karin M, Diaz-Meco MT. p62 in Cancer: Signaling Adaptor Beyond Autophagy. Cell. 2016; 167:606-09. https://doi.org/10.1016/j.cell.2016.09.030.

62. Shi LY, Han Z, Li XX, Li M, Han H, Chen J, Zang S. Inactivated Sendai virus strain Tianjin induces apoptosis in breast cancer MCF-7 cells by promoting caspase activation and Fas/FasL expression. Cancer Biother Radiopharm. 2015; 30:33-40. https://doi.org/10.1089/cbr.2014.1704.

63. Tsai JR, Chong IW, Chen YH, Hwang JJ, Yin WH, Chen HL, Chou SH, Chiu CC, Liu PL. Magnolol induces apoptosis via caspase-independent pathways in non-small cell lung cancer cells. Arch Pharm Res. 2014; 37:548-57. https://doi.org/10.1007/s12272-013-0232-1. 
64. Zhang L, Zhang S. Modulating Bcl-2 family proteins and caspase-3 in induction of apoptosis by paeoniflorin in human cervical cancer cells. Phytother Res. 2011; 25:155157. https://doi.org/10.1002/ptr.3534.

65. Chen CY, Liu TZ, Tseng WC, Lu FJ, Hung RP, Chen CH, Chen CH. (-)-Anonaine induces apoptosis through Baxand caspase-dependent pathways in human cervical cancer (HeLa) cells. Food Chem Toxicol. 2008; 46:2694-702. https://doi.org/10.1016/j.fct.2008.04.024.

66. Muthalagu N, Junttila MR, Wiese KE, Wolf E, Morton J, Bauer B, Evan GI, Eilers M, Murphy DJ. BIM is the primary mediator of MYC-induced apoptosis in multiple solid tissues. Cell Reports. 2014; 8:1347-53. https://doi. org/10.1016/j.celrep.2014.07.057.

67. Ling H, Zhou L, Jia X, Gapter LA, Agarwal R, Ng KY. Polyporenic acid $\mathrm{C}$ induces caspase-8-mediated apoptosis in human lung cancer A549 cells. Mol Carcinog. 2009; 48:498-507. https://doi.org/10.1002/mc.20487.

68. Jeong JW, Lee WS, Go SI, Nagappan A, Baek JY, Lee JD, Lee SJ, Park C, Kim GY, Kim HJ, Kim GS, Kwon TK, Ryu $\mathrm{CH}$, et al. Pachymic Acid Induces Apoptosis of EJ Bladder Cancer Cells by DR5 Up-Regulation, ROS Generation, Modulation of Bcl-2 and IAP Family Members. Phytother Res. 2015; 29:1516-24. https://doi.org/10.1002/ptr.5402.

69. Zhao R, Chen M, Jiang Z, Zhao F, Xi B, Zhang X, Fu H, Zhou K. Platycodin-D Induced Autophagy in Non-Small Cell Lung Cancer Cells via PI3K/Akt/mTOR and MAPK Signaling Pathways. J Cancer. 2015; 6:623-31. https://doi. org/10.7150/jca.11291.

70. Nagappan A, Lee WS, Yun JW, Lu JN, Chang SH, Jeong JH, Kim GS, Jung JM, Hong SC. Tetraarsenic hexoxide induces G2/M arrest, apoptosis, and autophagy via PI3K/
Akt suppression and p38 MAPK activation in SW620 human colon cancer cells. PLoS One. 2017; 12:e0174591. https://doi.org/10.1371/journal.pone.0174591.

71. Xu L, Zhang X, Li Y, Lu S, Lu S, Li J, Wang Y, Tian X, Wei JJ, Shao C, Liu Z. Neferine induces autophagy of human ovarian cancer cells via p38 MAPK/ JNK activation. Tumour Biol. 2016; 37:8721-29. https://doi.org/10.1007/ s13277-015-4737-8.

72. Zhao R, Chen M, Jiang Z, Zhao F, Xi B, Zhang X, Fu H, Zhou K. Platycodin-D Induced Autophagy in Non-Small Cell Lung Cancer Cells via PI3K/Akt/mTOR and MAPK Signaling Pathways. J Cancer. 2015; 6:623-31. https://doi. org/10.7150/jca.11291.

73. Xue JF, Shi ZM, Zou J, Li XL. Inhibition of PI3K/AKT/ mTOR signaling pathway promotes autophagy of articular chondrocytes and attenuates inflammatory response in rats with osteoarthritis. Biomed Pharmacother. 2017; 89:125261. https://doi.org/10.1016/j.biopha.2017.01.130.

74. Marotta LL, Almendro V, Marusyk A, Shipitsin M, Schemme J, Walker SR, Bloushtain-Qimron N, Kim JJ, Choudhury SA, Maruyama R, Wu Z, Gönen M, Mulvey LA, et al. The JAK2/STAT3 signaling pathway is required for growth of $\mathrm{CD} 44^{+} \mathrm{CD} 24^{-}$stem cell-like breast cancer cells in human tumors. J Clin Invest. 2011; 121:2723-35. https://doi.org/10.1172/JCI44745.

75. Jo M, Park MH, Kollipara PS, An BJ, Song HS, Han SB, Kim JH, Song MJ, Hong JT. Anti-cancer effect of bee venom toxin and melittin in ovarian cancer cells through induction of death receptors and inhibition of JAK2/STAT3 pathway. Toxicol Appl Pharmacol. 2012; 258:72-81. https:// doi.org/10.1016/j.taap.2011.10.009. 